\title{
Income Losses and Subjective Well-Being: Gender and Ethnic Inequalities during the Covid-19 Lockdown Period in the UK
}

Eleftherios Giovanis ( $\sim$ L.giovanis@mmu.ac.uk)

Manchester Metropolitan University

Oznur Ozdamar

Izmir Bakircay University

\section{Research Article}

Keywords: Covid-19, Difference-in-Differences, Ethnicity, Gender, Happiness, Mental Well-being

Posted Date: December 22nd, 2020

DOI: https://doi.org/10.21203/rs.3.rs-132600/v1

License: (c) (i) This work is licensed under a Creative Commons Attribution 4.0 International License.

Read Full License 


\section{Abstract}

COVID-19 has become a global health pandemic forcing governments introducing unprecedented steps to contain the spread of the virus. On the $23^{\text {rd }}$ of March, 2020, the UK government addressed the nation to announce extraordinary measures as a response to slow down the spread of the coronavirus, which have influenced the well-being and finances of millions of people. As a result people had to make difficult adjustments and to follow different coping strategies in order to respond to income losses. The main objective of this study is to examine the impact of various coping strategies, due to the lockdown measures, on the respondents' subjective well-being by gender and ethnic background. We apply a difference-in-differences framework using data from the UK Household Longitudinal Study (UKHLS) combined with the UKHLS COVID-19 survey conducted in April 2020. Furthermore, using the Life Satisfaction Approach (LSA), we estimate the well-being costs of the coping strategies adopted that denote the amount required to revert individual's well-being into the levels were before Covid-19 period. The results show that coping strategies with the earning losses have a significant detrimental impact on well-being and the related costs range between $£ 250-3,500$, which are significantly varied by gender and ethnic group.

JEL Classification: C1, I14, I31

\section{Introduction}

COVID-19 is a global health pandemic, which has forced governments around the globe to introduce unprecedented steps and measures to contain the spread of the virus. These steps include lockdowns restrictions by shutting down public places, such as schools, shopping malls, bars- restaurants, sport and cultural institutions, and businesses, and facilitating social distancing measures. The consequences were an unprecedented shut-down of public life, a prolonged material deprivation and deterioration in the mental and psychological well-being of the majority of citizens. The UK government on $23^{\text {rd }}$ of March, 2020 has decided to implement various lockdown measures and it has shut down schools, firms, social venues, and banned communication outside home and all "non-essential" travels. The UK economy, as many other developed and developing economies, is projected to severely suffer from a prolonged shutdown resulting to a sharp increase in unemployment and large reduction in mental well-being (Adams-Prassl et al., 2020; Etheridge and Spantig, 2020; Holmes et al., 2020; Leslie and McCurdy, 2020).

Although lock-down measures are cautiously being lifted, bringing slowly people back to work and their "normal" lives slowly, the financial, mental and psychological well-being has, undoubtedly, been negatively affected in the short term. In particular, many individuals and their families have experienced wage cuts, employment losses and significant drop in their living standards. The rapid and persistent decrease in earnings, which follow losses of jobs or cuts in wages and working hours, typically force people to strenuously adjust their finances, which affect adversely their quality of life, housing, nutrition and so forth (Eliason and Storrie, 2006). 
According to the study by Leslie and McCurdy (2020), the 68 percent of the UK households whose finances have been affected by the lockdown measures, have reported that have experienced a decline in income. The 23 percent of the affected households had to use their savings to cover the living costs and 13 percent was struggling to pay utility bills. Moreover, decline in household income has been mainly driven by falls in employment and working hours and cuts in wage rates, wile for wealthier households, falls in household income was associated with decline in investment income.

Financial strain has been found to be a significant predictor of psychological distress, leading to traumatic and stressful life experiences, which can further aggravate mental disorders and illnesses. Numerous research studies, across various disciplines ranging from health and medical, to sociology, psychology and economic sciences, have shown that unemployment and material deprivation are related to poor psychological and mental well-being (Kessler et al., 1987; Jacobson et al., 1993; Kasl and Jones, 2000; Booker and Sacker, 2012; Chang et al., 2013).

Our paper focuses on the identification of the causal impact of coping strategies adopted by households for handling earning losses on well-being. We apply a difference-in-differences (DiD) design, to investigate this impact on the mental and psychological well-being measured by the 12-item General Health Questionnaire (GHQ-12), as well as, on general happiness and its various components, such as anxiety-depression, feeling worthless, losing confidence. Next, using the life satisfaction approach (LSA), we will estimate the costs associated with coping strategies taken by the households, which show the amount of money required to compensate people in the UK, such that their well-being reverts back to the levels they were before the Covid-19 and the lockdown measures. Coping strategies include cuts in spending, use of savings and borrowing from banks and friends. To the best of our knowledge, so far, there has been little research undertaken about the broader social and well-being impacts of COVID-19 and the estimation of the well-being costs, especially across gender and ethnic groups. Furthermore, there is no study investigating and comparing the impact of coping strategies on well-being across gender and ethnic groups. The empirical analysis relies on data derived from the UK Household Longitudinal Study (UKHLS), a large nationally representative survey, over the waves 7-9 that cover the period 2015-2019, combined with the Understanding Society COVID-19 survey conducted in April, 2020.

The results suggest that the lockdown measures had a significant detrimental impact on income losses and the respondents' well-being. The findings suggest that both men and women have experienced a large fall in well-being, with a higher adverse effect on men's well-being who had to reduce spending or use from savings and had to borrow from banks, while women who had to borrow from family and friends have reported a larger deterioration in their well-being compared to men. Similar concluding remarks are derived from the estimates across ethnic groups, where the non-white ethnic minorities have been mostly affected by the Covid-19 pandemic. The costs or the amount required to compensate people for their reduction in well-being are ranging between $£ 250-3,500$ per month, corresponding to $£ 8$ and $£ 115$ per day, but these significantly vary, not only by gender and ethnic groups, but also by the coping strategy adopted and the SWB measures explored. 
The remaining sections are organised as follows: In section 2 we briefly discuss the earlier literature on the relationship between unemployment, loss in earnings and mental well-being. In section 3 we present the methodology applied, and we describe the data employed in the empirical work. In section 4 we report and discuss the findings and in section 5 we present the main concluding remarks of our findings.

\section{Literature Review}

There are numerous studies exploring the impact of unemployment and income losses on mental health outcomes, and psychological well-being (McKee-Ryan et al., 2005; Booker and Sacker, 2012; Howe et al., 2012). Theodossiou (1998) has explored the impact of unemployment and income losses on mental distress using data from the 1992 British Household Panel Study (BHPS). The author has explored six measures of mental distress and the results found a significant and adverse impact of unemployment on self-esteem and general happiness, and a rise in anxiety, depression and loss of confidence.

The negative impact of income losses and joblessness can be even stronger during economic recession periods, as is the Covid-19 period explored in this study. Modrek et al. (2013) presenting a review of 172 English language studies published between the $1^{\text {st }}$ of January 1980 through $1^{\text {st }}$ April 2013, confirms a significant and negative impact of unemployment on mental health outcomes, especially during the economic recession periods. Overall, previous studies have estimated that economic recessions affect significantly population's health and psychological well-being, which applies mostly to the vulnerable groups (Zivin et al., 2011; Karanikolos et al., 2013).

Very recent studies have also explored the impact of the lockdown restrictions during the Covid-19 period in the UK. Davillas and Jones (2020) using data from the UKHLS wave 9 and the UKHLS COVID-19 survey conducted in April 2020 have found that the GHQ-12 increased to 28.3 percent in the Covid-19 period from 18.3 percent it was in the period before the lockdown restrictions. Similarly, Banks and Xu (2020) found that the permanently laid-off employees have experienced a significant drop in mental well-being. In similar study by Etheridge and Spantig (2020), individuals in the UK have experienced a significant drop in their subjective well-being (SWB), which is expressed by the General Health Questionnaire, with most notable decreases in the well-being of youth. Adams-Prassl et al. (2020) have also explored the impact of Covid-19 on individuals' SWB in Germany, USA and UK. Their findings suggest that employees whose only a small share of their tasks can be done from home are more likely to experience either a job loss or cuts in working hours and earnings. Furthermore, women and those with lower educational; attainment are more affected from the coronavirus pandemic crisis. However, these studies do not explore the impact of the lockdown measures on income losses, coping strategies adopted by the households and their impact on the mental well-being and happiness. Furthermore, they do not estimate the costs of well-being and the amount of money required to bring people's well-being back to levels they were before the outbreak of the Covid-19 pandemic.

Coping with particular stressors of income and job loss, is defined as a person's constantly changing cognitive and behavioural efforts to manage demands that are associated with unemployment and 
income loss and are appraised as exceeding the resources possessed by the individual (Folkman et al., 1986). In the earlier literature, coping strategies have mainly been conceptualized as either emotionfocused or problem-focused coping strategies (Hanisch, 1999). Emotion-focused coping involves ease of emotional distress induced by the stressor, through techniques such as avoidance, or minimizing the problem. Types of emotional coping with job and income loss include expressing frustration or sadness about not having a job, minimizing the intensity of the loss of a job or engaging in the community to support those who are also unemployed and have experienced income losses (Leana et al., 1998).

In contrast, problem- focused coping strategies require the systematic mitigation or elimination of the stressor by ideally taking a rational and logical intervention to tackle the source of the problem. For example, by pursuing training, looking for new employment actively, or relocating to another city for better work, (Leana et al., 1998). However, in our study we introduce alternative ways of problem-focused strategies, since the lockdown restrictions have prohibited relocations to other geographical areas, has disrupted the labour market and has frozen hiring opportunities.

Despite a large body in the unemployment literature, the coping processes and strategies specifically following job and income loss and their impact on SWB have received relatively little attention in existing research (McKee-Ryan et al., 2005; Solove et al., 2015). Our empirical analysis explores the lockdown measures that have potentially created an exogenous variation on income losses and the adjustments households had to make in order to cope with spending and living standards and to further explore the impact on well-being and estimate the related well-being costs. Behavioural economists and psychologists have argued that quality of life does not depend only on objective measures, such as labour market outcomes and material deprivation, but is a broader concept (Easterlin, 1974; Kahneman et al., 1997). Easterlin (1974) in his seminal study tried to identify the various dimensions of well-being and since then there is a well-documented literature attempting to explore the relationship between well-being and various factors, such as job satisfaction, air quality, income, and others (Clark and Oswald, 1994, 1996; Blanchflower and Oswald, 2004; Dolan et al., 2008; Levinson, 2012).

Hence, we further aim to calculate the well-being costs using the LSA, which denote the amount of money required to compensate people for their reduction in well-being due to coping strategies resulted from the Covid-19 lockdown restrictions. Numerous studies have employed the LSA as a method for the evaluation of public goods or bads, and for the estimation of the marginal willingness to pay or the calculation of costs in various topics ranging from air quality and environment (e.g. Frey et al., 2010; Levinson, 2012; Giovanis and Ozdamar, 2016) to crime and health care interventions (e.g. Ambrey et al., 2013; Howley, 2016). For instance, Blanchflower and Oswald (2011) using data on 48,000 individuals from the General Social Surveys of the United States during the period 1972-2008, have estimated that joblessness is associated with a large negative effect on happiness.

Furthermore, earlier studies have shown the negative association among income losses, unemployment and leisure-recreational activities, which in turn leads to further poorer levels of well-being (Wanberg et al., 1997; Selenko et al., 2011; Goodman et al., 2017). Hence, we also aim to evaluate the impact of lockdown 
measures and income losses on the General Happiness Questionnaire (GHQ), and its various components, such as loss of sleep; playing a useful role, feeling worthless; losing confidence, depression and satisfaction with daily activities.

\section{Data And Methods}

\subsection{Data}

The empirical analysis relies on data derived from the UK Household Longitudinal Study (UKHLS), a nationally representative longitudinal survey of approximately 40,000 households in the United Kingdom, which covers the geographical area of the countries England, Scotland, Wales and Northern Ireland. UKHLS started in 2009 and so far have been conducted 9 waves. For the purpose of our identification strategy we use the Waves 7-9 for the pre-Covid period, covering the period 2015-2019, combined with the Understanding Society COVID-19 survey conducted in April, 2020. The design of the UKHLS Covid-19 survey targets to make only minimal adjustments in the field questionnaires to ensure comparability of the data collected in the previous waves. The purpose of the design in the UKHLS COVID-19 survey is to cover the dynamic impact of the pandemic on the welfare of individuals, families and wider communities in the UK (Burton et al., 2020).

For the purpose of our identification strategy we use the waves 7-9, as we also aim to test for the DiD validity, which involves the "placebo" pre-treatment effects used to test the parallel trend assumption. We could have employed a shorter period, such as waves 8-9 or only wave 9 for the pre-Covid-19 period, but we would not be able to test for the parallel trend assumption using only one wave. Nevertheless, our main DiD estimates remain the same if we consider a shorter pre-treatment period.

We explore various subjective well-being (SWB) measures. The first is the 12 item General Health Questionnaire caseness score (GHQ-12), which is a well-documented and prominent measure in academic research. It is a multidimensional scale that assesses several distinct aspects of mental distress and it is correlated with other measures of SWB, including happiness, anxiety, depression and self-esteem (Tait, 2003; Del-Pilar Sánchez-López and Dresch, 2008; Romppel et al., 2013). The GHQ-12 takes values between 0 (excellent well-being) to 12 (very poor well-being).

The second measure is the general happiness, which answers to the question "What is your overall happiness" and the possible answers are four "More so than usual", "About the same as usual", "Less so than usual" and "Much less than usual". Similarly, we explore the other components of the General Happiness Questionnaire, which are presented in table 1.

In table 2, we report the means and standard deviations of the GHQ-12 before and during the Covid-19 period by different adjustments of coping with income losses. We do not report the descriptive statistics for the remained SWB measures, due to space limitations. Furthermore, the statistics in table 1 refer to 
the total sample, while our empirical analysis will investigate the impact of coping strategies on the SWB across gender and ethnic groups.

In the first treated group - those who have reduced spending to cope with earning losses- and the male group, we observe that GHQ-12 increased from 1.72 in the pre-Covid period to 2.91 during the Covid-19 period, compared to the control subjects, which report an increase from 1.17 to 1.73 . Similarly, we find large increases for males who used savings, increased from 1.81 to 3.44, those who borrowed from the bank and used credit card from 1.94 to 4.67 and those who have borrowed from relatives and friends increasing from 2.53 during the pre-Covid period to 4.96 in the Covid-19 period. The same concluding remarks are derived when we consider the females, where the increases in the treated groups are ranging between 1.1 and 2.7 units compared to the control group where GHQ-12 fell by almost 1.2 units (higher values imply lower levels of psychological and mental well-being). While earlier studies suggest that Covid-19 had affected mostly women, in terms of job losses (Alon et al., 2020; Adams-Prassl et al., 2020), the summary statistics in table 1 reveal a more complicated and mixed situation. In particular, we find that the effect varies by the type of the coping strategy undertaken. In particular, men's psychological well-being is negatively affected more by using savings and borrowing from banks compared to women, while the latter group is significantly more affected, compared to men, when they had to borrow from family, relatives and friends. This is in contrast to earlier studies, suggesting that women have experienced higher falls in well-being in the UK and USA (Alon et al., 2020; Adams-Prassl et al., 2020). Thus, the analysis may vary when we consider different coping strategies. While, due to space limitations we do not repeat the summary statistics for the components of the General Happiness Questionnaire, as well as, by ethnic groups, the main concluding remarks remain the same, where large increases are observed for those who have borrowed either from bank or friends and relatives, followed by those that had to use money from their savings or had to cut spending.

\subsection{Empirical Strategy}

The main aim of the study is to investigate the impact of different coping strategies of income losses, due to Covid-19 and the lockdown measures, on the 12-item GHQ and the components of happiness. We propose the following difference-in-differences (DiD) strategy:

$$
\begin{aligned}
& S W B_{i, r, t}=\beta_{0}+\beta_{1} C S_{i, r, t}+\beta_{2} \operatorname{covid}_{i, r, t}+\beta_{3}\left(C_{i, r, t} \cdot \operatorname{covid}_{i, r, t}\right)+\beta_{4} \text { logincome }_{i, r, t}+\beta^{\prime} \boldsymbol{X}_{i, r, t}+ \\
& \theta_{t}+l_{r}+l_{r} T+u_{i, r, t}
\end{aligned}
$$


In regression (1) SWB denotes the subjective well-being for individual $i$, in area $r$ and at time-wave $t$, while variable $C S$ denotes the coping strategies to income losses that we have described in the previous section. In particular, we define four treated groups. First, CS takes value 1 if the individual had to reduce spending and 0 otherwise. Similarly, for the second case it takes value 1 if the coping strategy adopted is use from savings and 0 otherwise. The third case is when the individual has borrowed money from bank or has used credit card, while in the fourth case CS takes value 1 if the individual has borrowed money from family, relatives and friends. The variable covid takes value 1 for the Covid-19 lockdown period and 0 for the pre-Covid-19 period (waves 7-9). Variable logincome is the logarithm of the monthly household income expressed in prices of 2019 and the average value is around $£ 4,200$.

Set $I_{r}$ indicates the area-government region fixed effects, time dummies, and specifically the month and the year of the interview, are expressed by the set $\theta_{t}$. Area-specific time trends denoted by the term $I_{r} T$ are also included in regression (1) to eliminate the effect of exogenous factors on changes in the outcomes that cannot be explained by the other variables. In particular, lockdown restrictions may have not the same impact on businesses, employment and individuals' income loss and well-being. Parameter $\beta_{3}$ is the DiD estimator that identifies the effect on the outcome variables of coping strategies to income losses on SWB. Based on the data availability in all waves of the UKHLS we employ, the control variables in vector $\mathbf{X}$ include gender, age, whether there is a child in the household, and the employment status.

We limit the sample of our analysis to those that have non-missing values in all four waves of the survey and we cluster the standard errors at the individual level. This results to 40,100 observations and 10,025 individuals; 5,804 females and 4,221 males. Moreover, to avoid sample attrition and biased statistical inference we adjust our regressions accounting for the weight of the survey design (Chen et al., 2015).

Following the estimation of the DiD (1), we will calculate the marginal costs of well-being, and this will reveal how much money should be allocated to compensate people for experiencing lower levels of SWB making different adjustments, due to income losses resulted from the lockdown restrictions. Using the LSA this can be done as:

$$
S W B C=- \text { dlogincome } / d D i D=-(\partial S W B / \partial D i D) /(\partial S W B /(\partial \text { logincome })
$$

Where we denote the subjective well-being costs by $S W B C$, which is invariant to any monotonic transformation of the SWB function, as no cardinal utility function is required (Frey et al., 2010). This will be equal to the first derivative of the $S W B$ with respect to the DiD estimator, which is the coefficient $\beta_{3}$ in equation (1), over the first derivative of the SWB function with respect to the logarithm of the monthly household income or the parameter $\beta_{4}$. We do not further discuss the LSA, as well as, its advantages and limitations compared to the hedonic price analysis and the contingent evaluation techniques, since it is out of the current study's topic and it has been extensively explored and it is well-documented in the literature (e.g. Frey et al., 2010; Levinson, 2012; Giovanis and Ozdamar, 2016). 
As a robustness check we will report the estimates derived from the ordered Logit model and the Fixed Effects-OLS model for males, as the estimates for the other groups remain similar. In particular, we are interested for the $S W B C$ and not for the individual coefficients, which is also supported by earlier studies (e.g. Ferrer and Frijters, 2004). Furthermore, it is important to test for the parallel trend hypothesis. One common approach is to use leads and lags of the DiD estimator and to test whether there is an anticipatory effect. However, since we have only one post-shock period-the lockdown period- we cannot implement this test. An alternative way is to use interaction terms of the CS (treatment) and the time trend variable $t$ (see Angrist and Pischke, 2008 for more details):

$$
S W B_{i, r, t}=\sum_{t=q}^{n} \beta_{q}\left(C S_{i, r, t-q} \cdot t_{t-q}\right)+\beta^{\prime} \boldsymbol{X}_{i, r, t}+\theta_{t}+l_{r}+u_{i, r, t}
$$

Where ${ }^{C S_{i, r, t-q} \cdot t_{t-q}}$ is showing whether the treatment-Covid-19 lockdown is switched on in period $t$, and the lags of the treatment are expressed respectively by $q=0,1,2$ where $q=0$ corresponds to the Covid- 19 lockdown period and lags $q=1,2$ correspond to waves $8-9$. We will perform a joint hypothesis testing for the coefficients of the lagged interaction terms of $C S$ and the time trend $t$, where the null hypothesis implies that the parallel trend assumption holds. We should notice that we do not include the interaction term for wave 7 , which corresponds to the lag $q=3$, as this is dropped due to multicollinearity.

\section{Empirical Results And Discussion}

In table 3 and panels A1-A4 we report the estimates of the DiD (1) for the coping strategies explored and the males group, while in panels B1-B4 we present the DiD estimates for the female group. The findings are quite mixed, as we find differences not only between the coping strategies within each group, but also between men and women. Furthermore, large differences are reported in the well-being outcomes explored. As we mentioned earlier, recent studies found that women have experienced a worse deterioration in mental health and well-being compared to men (Alon et al. (2020; Adams-Prassl et al., 2020; Etheridge and Spantig, 2020). However, while our results confirm these findings, this takes place only partly, as the effects of the coping strategies vary between men and women. In particular, when we consider the coping strategy reduction in spending, men report a higher drop in GHQ-12 and general happiness compared to women, which is also shown from the higher well-being costs. The costs for the GHQ-12 is almost doubled at $£ 800$ for men and $£ 450$ for women, and the costs for happiness of men reach $£ 630$, while the impact of reduction in spending on women's happiness is found insignificant. Furthermore, we find a significant and adverse impact of the particular coping strategy in a larger set of the general happiness questionnaire's outcomes for men, ranging between $£ 300$ about the belief of worthless and up to $£ 1,300$ for the loss of sleep followed by playing a useful role at $£ 1,130$. In contrast, we find the well-being costs for women significantly lower, except for the well-being measure of playing a useful role at $£ 1,000$. 
Similar conclusions are derived when we explore the coping strategy of using from savings, where the well-being costs for the GHQ-12 and happiness are respectively $£ 1,650$ and $£ 1,500$ for men, and $£ 700$ and $£ 600$ for women. The latter group values more the well-being measures of playing a useful role and capable of making decisions with $£ 1,700$ and $£ 1,800$ respectively. As in the case of the coping strategy reduction in spending, men are affected in 8 SWB measures compared to 6 SWB measures in the women's group.

Similarly, when we explore the coping strategy of borrowing from banks or using credit cards, the wellbeing costs for the GHQ-12 and happiness are respectively $£ 2,400$ and $£ 2,800$ for men. On the other hand, the well-being costs for the GHQ-12 are $£ 1,500$ for women, while we found an insignificant impact of this coping strategy on their general happiness. Moreover, the specific coping strategy affects adversely all the SWB measures we explore in the male group and it affects negatively 8 SWB measures in the female group. However, women value more the well-being measure of being constantly under strain and playing a useful role at $£ 2,400$ and $£ 2,300$ followed by the measure of capability of making decisions at $£ 2,000$.

In contrast, borrowing from relatives and friends is associated with higher well-being costs for women, which affects 10 SWB measures compared to 6 SWB measures for men. The specific coping strategy has no impact on men's happiness, while the strongest effects are reported in the regressions of GHQ-12, playing a useful role and capable of making decisions with the well-being costs being equal at $£ 2,000$, $£ 1,850$ and $£ 1,700$ respectively. On the other hand, the well-being costs for women are ranging between $£ 2,100$ and $£ 3,000$, with the SWB measure of the problem overcoming difficulties presenting the highest costs, followed by happiness at $£ 2,800$, the ability to face problems at $£ 2,700$ and the GHQ-12 and playing a useful role at $£ 2,600$.

Thus, one main concluding remark is that not only women, but also men have been significantly affected by the income losses and the coping strategies they had to undertake. The results are not in perfect line with previous studies (Alon et al. (2020; Adams-Prassl et al., 2020; Etheridge and Spantig, 2020) as the gender inequalities, in terms of well-being costs due to lockdown restrictions, income losses and coping strategies, vary by the coping strategy and the SWB measures explored. In particular, we found significant inequalities in the coping strategies of reduction in spending and use of savings, where the well-being costs for men are significantly higher compared to women, while the coping strategy of borrowing from relatives and friends is associated with higher costs for women. Furthermore, for the coping strategy of borrowing from banks, we find significant gender inequalities in different domains of SWB, where men are mostly affected in terms of the GHQ-12, happiness and depression, while this coping strategy has a higher impact on the well-being of women who are constantly under strain or whether they play a useful role.

In all cases, based on the F-statistic test we accept the null hypothesis of the parallel trend assumption, and therefore, we argue that the DiD design is valid. This is also confirmed by the figures 1-8, where in figures 1-4 we show the GHQ-12 for the four treated and control groups for males, while in figures 5-8 we 
illustrate the respective graphs for females. The periods 1-3 correspond to waves 7-9 and period 4 refers to the Covid-19 period.

It becomes clear that before the lockdown measures, both treated and control groups were following the same trend, while a significant jump upwards is observed for both groups, indicating that the GHQ-12 is significantly increased, implying a deterioration in psychological distress and mental well-being, during the Covid-19 period, as we have shown in table 2. However, the jump is significantly higher for the treated group, those who had to make difficult adjustments and use the coping strategies we explore. We do not present the figures for the components of the General Happiness questionnaire, since we reach to similar conclusions. Furthermore, we do not illustrate the figures across ethnic groups for the same reason. Nevertheless, we provide in all regressions, the F-statistic test for the parallel trend assumption, which is derived from regression (3). We have also estimated the DiD regressions without controls and the DiD estimator remains almost the same, which further supports the robustness of our results and the strength of the research design. Thus, overall, it seems that both treated and control subjects would follow the same trend in the two outcomes we explore in the absence of the lockdown and the coping strategies.

In table 4 we report the estimates for the GHQ-12 and general happiness across ethnic groups, and in particular, for the White British; those with other white background; mixed white; those with an Indian, Bangladeshi or Pakistani background; for Asians, and the final group consists of Black Caribbean, Africans and Arabs. We report the estimates for the GHQ-12 and the general happiness, as the concluding remarks derived from the remained SWB measures and the ethnic inequalities revealed, remain similar. White British report the highest GHQ-12 costs when they borrow from banks at $£ 1,800$ followed by use from savings at $£ 1,300$, and reduction in spending at $£ 400$, while borrowing from friends and relatives is marginally insignificant. On the other hand, the happiness costs reach $£ 2,850$ when the particular ethnic group had to borrow from friends and relatives, which is significantly higher and almost doubled than the happiness costs derived from the coping strategy of borrowing from banks valued at $£ 1,450$.

One possible explanation for the insignificant impact of borrowing from friends on GHQ-12 is that it may reduce financial strain and build a sense of social connection and inclusion. However, borrowing from friends and family may generate feelings of depression, guilt and shame (Wherry et al., 2019) that may affect the general happiness. Furthermore, even though we found a significant and negative impact of this coping strategy on the well-being of both men and women, the significance comes from the very large adverse effect this coping strategy has to the SWB of the other ethnic groups explored. When we consider the non-British whites, we find that the coping strategies had a significantly larger negative impact on their psychological distress and well-being expressed by GHQ-12 reaching the $£ 2,800$ when they borrow from banks or use their credit card, at $£ 2,700$ when they borrow from relatives and friends, and $£ 1,400$ when they reduce their spending, while no effect is found for the coping strategy of using from savings. On the other hand, the inequalities between white British and other whites are higher, as we find no impact in the happiness of the last group, except for the case of the coping strategy, using from 
savings. Thus, it is important to explore at least two different measures of SWB, as the GHQ-12 measures the mental health and psychological distress, while happiness can be related with emotions like guilty and shame, as well as, with the overall life satisfaction. This can be shown from the last coping strategy, which is borrowing from relatives and friends, where other whites may not feel shame or guilty compared to white British, but they express more concerns about their psychological well-being. When we explore the ethnic group of mixed whites, the inequalities between them and white British persist in terms of happiness, where the well-being costs for the former group reach $£ 3,600$ when they borrow from banks, followed by borrowing from friends and relatives and reduction in spending at $£ 2,900$ and $£ 1,580$ respectively. On the other hand, the impact of coping strategies have a more unfavourable and unequal impact on the well-being of white British regarding the GHQ-12, since the impact on the GHQ-12 of white mixed is insignificant except for the reduction in spending, which is valued at $£ 1,300$, implying that ethnic inequalities vary by the type of the SWB measures explored.

Similar concluding remarks are derived when we consider the ethnic group consisting of Bangladeshis, Indians and Pakistanis, who report significant lower levels of general happiness, except from borrowing from banks, valued at $£ 3,000$ when they borrow from friends, $£ 2,850$ when they use savings and $£ 2,850$ and $£ 2,550$ when they had to cut spending. Regarding the GHQ-12 we find a significant impact only at the reduction in spending regression valued at $£ 3,200$ and borrowing from banks valued at $£ 1,400$. The next group explored is Asians, who interestingly have not been affected by the coping strategies of reduction in spending and use from savings, but the well-being costs, when they borrow from relatives and friends, are significantly larger compared to the white British and other whites, estimated at $£ 2,900$ for the GHQ12 and $£ 3,500$ for the general happiness. Furthermore, we should notice that we do not report the estimates for the coping strategy of borrowing from banks or use credit card, as in the Covid-19 survey sample, this group has not reported that has adopted this type of adjustment to income losses.

Finally, for the last ethnic group that consists of Blacks and Arabs, we find the largest negative impact on happiness when they have to borrow either from banks or from friends and relatives with their associated costs being estimated between $£ 3,250-3,400$, while they are less affected when they have to make alternative adjustments, such as reduce spending or use from their savings.

Due to space limitations, we have reported and discussed only the impact of coping strategies on GHQ-12 and happiness, while the well-being costs vary by the SWB measure. Nevertheless, our main conclusions remain the same and are consistent with earlier studies (Hu, 2020), where non-white ethnic minorities have experienced a significant larger fall in their well-being. Moreover, based on the F-statistic test we accept the null hypothesis of the parallel trend assumption, except for the other whites group and the regression of the general happiness, where we reject the null hypothesis at the 10 percent significance level.

Overall, the findings are consistent with the study by Fujiwara et al. (2020), who found the daily total wellbeing cost to adults in the UK to be around $£ 2$.25bn per day, corresponding to around $£ 43$ per adult per day. However, our estimates and well-being costs differ, since we explore different measures of SWB 
compared to their study. For instance, given the minimum and maximum values found across gender and ethnic groups, which are $£ 250$ and $£ 3,500$, the daily well-being cost is $£ 8$ and $£ 115$ per day respectively, indicating that an investigation in different SWB domains provides a broader picture about the impact of the coping strategies we explore on the well-being.

In table 5 we report also the estimates derived by the Ordered Logit in panel A, the Fixed Effects OLS in panel $\mathrm{B}$ and the Random Effects Ordered Logit in panel $\mathrm{C}$ for the males who adopted the reduction in spending as the coping strategy, as the results for the remained coping strategies across the gender and ethnic groups remain similar with those derived in tables 3-4. While the estimated coefficients differ in each method, it is important to compare the well-being costs derived from equation (2). As we can see, the costs are similar with those found in panel A of table 1.

However, one criticism is that the parallel trend assumption does not consider whether the treated and control subjects share similar outcomes before the Covid-19 pandemic. In particular, as we have shown in figures 1-8, and based on the F-statistic tests in tables 3-4, even though the parallel tend assumption appears to hold, we observe that the outcome, which is the GHQ-12, is not the same between treated and controls. Thus, those who had to adopt the coping strategies explored, report lower psychological wellbeing levels before the Covid-19 lockdown period. Therefore, we will match the treated and control groups, in the pre-Covid-19 period in such a way that the SWB outcomes, and in particular the GHQ-12 and the general happiness, will be very similar between the two groups. While there is a very extensive and well-documented literature on the propensity score matching (PSM), we employ the nearest neighbour algorithm with replacement and caliper of value 0.1 . Furthermore, since the number of control subjects-those who did not had adopt a coping strategy- is large, the matching will not be associated with higher variance, while still the bias can be very low (see for more details Caliendo and Kopeinig, 2008 on the PSM). Next, we employ a DiD-PSM, which is just the DiD design using the matched sample.

Regarding the well-being costs, the values found and reported in panel $D$ of table 5 are very close to those presented in panel A of table 1. More specifically, for the GHQ-12 and happiness the well-being costs found with the DiD are equal at $£ 800$ and $£ 630$ respectively, while the respective values derived from the DiD-PSM are $£ 840$ and $£ 660$. Furthermore, in figures $9-10$ we present the average outcome of males' GHQ-12 and general happiness when the reduction in spending as a coping strategy is considered.

\section{Conclusions}

In this study we have attempted to explore the impact of coping strategies and hard adjustments that individuals have undertaken during the Covid-19 lockdown period, on mental well-being and various components of the general happiness questionnaire. Furthermore, we estimated the well-being costs, which correspond to the amount required to revert people's well-being to the levels they were before the spread of the Covid-19 pandemic and the lockdown restrictions that have led people to undertake strategies to cope with the income losses. 
As we have shown, the unequal distribution and impact of coping strategies varies not only by gender, but also by the type of the coping strategy and the SWB measure explored. In particular, men's well-being is significantly affected more than women, when they have to borrow from banks or they cut spending, while women are affected more when they borrow from relatives and friends. On the other hand, we found overall significant differences in the well-being costs across the ethnic groups explored, with the non-white ethnic minorities being hit more compared to the white British and white non-British, revealing the inequalities might be present in the UK society and economy. Furthermore, the impact of coping strategies varies not only between genders and ethnic groups, but also within the same ethnic or gender group and the SWB measures, indicating that a more in-depth investigation regarding the different domains of well-being is required.

In terms of policy implications, our findings suggest a strong adverse, unfavourable, and unequal impact of social distancing and lockdown restrictions on mental well-being and happiness. Therefore, our results can inform and provide insights to policy makers who must determine and weigh up a large range of conflicting objectives, such as mental and physical health, employment, inequalities and happiness. This study may provide complementary inputs in previous studies that have explored the impact of the coronavirus pandemic on job losses and well-being.

However, the study is not without drawbacks and limitations. First, we have not explored the impact of coping strategies across other socio-economic and demographic characteristics, such as age groups, educational attainment, working experience and industry, and marital status. Nevertheless, the aim of this study was to explore the impact of coping strategies on mental well-being and happiness, due to Covid19 lockdown restrictions, and to present a method of estimating the well-being costs of coping strategies. Further studies may consider also the role of family responsibilities, childcare and housework, the impact of Covid-19 on job losses and coping strategies by age and education, as well as, the role of teleworking and working at home.

\section{Declarations}

\section{Compliance with Ethical Standards}

Conflict of interest The authors declare that have no conflict of interest.

Compliance of ethical standard statement This article does not contain any studies with human participants or animals performed by the authors

Informed consent: Informed consent was not sought for the present study because the study is based on secondary data. The authors have been granted with access to the data. 


\section{References}

Adams-Prassl, A., Boneva, T., Golin, M. and Rauh, C. (2020). Inequality in the impact of the coronavirus shock: Evidence from real time surveys. IZA Discussion Paper No. 13183, Bonn, Germany.

Alon, T. M., Doepke, M., Olmstead-Rumsey, J. and Tertilt, M. (2020). The impact of COVID-19 on gender equality, WP No. w26947. National Bureau of Economic Research, Cambridge, USA.

Ambrey, C. L., Fleming, C. and Manning, M. (2013). The life satisfaction approach to estimating the cost of crime: An individual's willingness-to-pay for crime reduction. Australia: Griffith Business School. https://melbourneinstitute.unimelb.edu.au/assets/documents/hilda-bibliography/working-discussionresearch-papers/2013/Ambrey_etal_-the-life-satisfaction-approach-to-estimating-the-cost-of-crime.pdf.

Angrist, J.D. and Pischke, J.S. (2008). Mostly harmless econometrics: An empiricist's companion. Princeton University Press.

Banks, J. and Xu, X. (2020). The mental health effects of the first two months of lockdown and social distancing during the Covid-19 pandemic in the UK. IFS Working Paper W20/16, IFS -

https://www.ifs.org.uk/uploads/The-mental-health-effects-of-the-first-two-months-of-lockdown-andsocial-distancing-during-the-Covid-19-pandemic-in-the-UK.pdf.

Blanchflower, D. G. and Oswald, A. J. (2004). Money, sex and happiness: An empirical study. Scandinavian Journal of Economics, 106(3), 393-415.

Blanchflower, D. G. and Oswald, A. J. (2011). International happiness: A new view on the measure of performance. Academy of Management Perspectives, 25(1), 6-22.

Booker, C. L. and Sacker, A. (2012). Psychological well-being and reactions to multiple unemployment events: adaptation or sensitisation? Journal of Epidemiology and Community Health, 66(9), 832-838.

Burton, J., Lynn, P. and Benzeval, M. (2020). How Understanding Society: The UK household longitudinal study adapted to the COVID-19 pandemic. Survey Research Methods, 14(2), 235-239.

Caliendo, M. and Kopeinig, S. (2008). Some practical guidance for the implementation of propensity score matching. Journal of Economic Surveys, 22(1), 31-72.

Chang, S. S., Stuckler, D., Yip, P. and Gunnell, D. (2013). Impact of 2008 global economic crisis on suicide: time trend study in 54 countries. The British Medical Journal, 347, f5239.

Chen, Q., Gelman, A., Tracy, M., Norris, F. H. and Galea, S. (2015). Incorporating the sampling design in weighting adjustments for panel attrition. Statistics in Medicine, 34(28), 3637-3647.

Clark, A.E. and Oswald, A.J. (1994). Unhappiness and unemployment. The Economic Journal, 104, 648659. 
Clark, A.E. and Oswald, A.J. (1996). Satisfaction and comparison income. Journal of Public Economics, 61, 359-381.

Davillas, A. and Jones, A. M. (2020). The COVID-19 pandemic and its impact on inequality of opportunity in psychological distress in the UK. GLO Discussion Paper Series 567, Global Labor Organization (GLO), Essen.

Decancq, K. and Schokkaert, E. (2016). Beyond GDP: Using equivalent incomes to measure well-being in Europe. Social Indicators Research, 126(1), 21-55.

Del-Pilar Sánchez-López, M. and Dresch, V. (2008) The 12-Item General Health Questionnaire (GHQ-12): Reliability, External Validity and Factor Structure in the Spanish Population. Psicothema, 20(4), 839-843.

Dolan, P. and Kahneman, D. (2008). Interpretations of Utility and their Implications for the Valuation of Health. The Economic Journal, 118(525), 215-234.

Easterlin, R. A. (1974). Does Economic Growth Improve the Human Lot? Some Empirical Evidence. In Nations and Households in Economic Growth: Essays in Honor of Moses Abramovitz. David, P. A. and Reder, M.W. (Eds). Academic Press, pp. 89-125.

Eliason, M. and Storrie, D. (2006). Lasting or latent scars? Swedish evidence on the long-term effects of job displacement. Journal of Labor Economics, 24(4), 831-856.

Etheridge, B. and Spantig, L. (2020). The gender gap in mental well-being during the Covid-19 outbreak: evidence from the UK, WP No. 2020-08. Institute for Social and Economic Research.

Ferrer-i-Carbonell, A. and Frijters, P. (2004). How important is methodology for the estimates of the determinants of Happiness? Economic Journal, 114(497), 641-659.

Folkman, S., Lazarus, R. S., Dunkel-Schetter, C., DeLongis, A. and Gruen, R. J. (1986). Dynamics of a stressful encounter: Cognitive appraisal, coping, and encounter outcomes. Journal of Personality and Social Psychology, 50(5), 992-1103.

Frey, B. S., Luechinger, S. and Stutzer, A. (2010). The life satisfaction approach to environmental valuation. Annual Review of Resource Economics, 2(1), 139-160.

Fujiwara, D., Dolan, P., Lawton, R., Behzadnejad, F., Lagarde, A., Maxwell, C. and Peytrignet, S. (2020). The Wellbeing Costs of COVID-19 in the UK. An Independent Research Report by Simetrica-Jacobs and the London School of Economics and Political Science. https://www.jacobs.com/sites/default/files/202005/jacobs-wellbeing-costs-of-covid-19-uk.pdf

Giovanis, E. and Ozdamar, O. (2016). Structural Equation Modelling and the Causal Effect of Permanent Income on Life Satisfaction: The Case of Air Pollution Valuation in Switzerland. Journal of Economic Surveys, 30(3), 430-459. 
Goodman, W. K., Geiger, A. M. and Wolf, J. M. (2017). Leisure activities are linked to mental health benefits by providing time structure: comparing employed, unemployed and homemakers. Journal of Epidemiology and Community Health, 71(1), 4-11.

Hanisch, K. A. (1999). Job loss and unemployment research from 1994 to 1998: A review and recommendations for research and intervention. Journal of Vocational Behavior, 55(2), 188-220.

Holmes, E. A., O' Connor, R. C., Perry, V. H., Tracey, I., Wessely, S., Arseneault, L., et al. (2020). Multidisciplinary research priorities for the COVID-19 pandemic: a call for action for mental health science. The Lancet Psychiatry, 7, 547-560.

Howe, G. W., Hornberger, A. P., Weihs, K., Moreno, F. and Neiderhiser, J. M. (2012). Higher-order structure in the trajectories of depression and anxiety following sudden involuntary unemployment. Journal of Abnormal Osychology, 121(2), 325.

Howley, P. (2016). Valuing the benefits from health care interventions using life satisfaction data. Health and Econometrics Data Group University of York, 16(01).

https://www.york.ac.uk/media/economics/documents/hedg/workingpapers/1601.pdf.

$\mathrm{Hu}, \mathrm{Y}$. (2020). Intersecting ethnic and native-migrant inequalities in the economic impact of the COVID-19 pandemic in the UK. Research in Social Stratification and Mobility, 100528.

Jacobson, L. S., LaLonde, R. J., \& Sullivan, D. G. (1993). Earnings losses of displaced workers. The American Economic Review, 83(4), 685-709.

Kahneman, D., Wakker, P. P. and Sarin, R. (1997). Back to Bentham? Explorations of Experienced Utility. The Quarterly Journal of Economics, 112(2), 375-405.

Karanikolos, M., Mladovsky, P., Cylus, J., Thomson, S., Basu, S., Stuckler, D., Mackenbach, J.P. and McKee, M. (2013). Financial crisis, austerity, and health in Europe. The Lancet, 381(9874), 1323-1331.

Kasl, S.V. and Jones, B.A. (2000). The impact of job loss and retirement on health. In: Berkman, L.F. and Kawachi, I. (Eds.) Social Epidemiology, 118-136. Oxford University Press, Oxford.

Kessler, R. C., Turner, J. B. and House, J. S. (1987). Intervening processes in the relationship between unemployment and health. Psychological Medicine, 17(4), 949-961.

Leana, C. R., Feldman, D. C., \& Tan, G. Y. (1998). Predictors of coping behavior after a layoff. Journal of Organizational Behavior: The International Journal of Industrial, Occupational and Organizational Psychology and Behavior, 19(1), 85-97.

Leslie, J. and McCurdy, C. (2020). The economic effects of coronavirus in the UK: Utilising timely economic indicators. https://www.resolutionfoundation.org/app/uploads/2020/04/The-economiceffects-of-coronavirus-in-the-UK-fast-indicators-8th-ed.pdf. 
Levinson, A. (2012). Valuing Public Goods Using Happiness Data: The Case of Air Quality. Journal of Public Economics, 96, 869-880.

McKee-Ryan, F., Song, Z., Wanberg, C. R. and Kinicki, A. J. (2005). Psychological and physical well-being during unemployment: a meta-analytic study. Journal of Applied Psychology, 90(1), 53.

Modrek, S., Stuckler, D., McKee, M., Cullen, M. R. and Basu, S. (2013). A review of health consequences of recessions internationally and a synthesis of the US response during the Great Recession. Public Health Reviews, 35(1), 10.

Romppel, M. Braehler, E. Roth, M. and Glaesmer, H. (2013) What Is the General Health Questionnaire-12 Assessing? Dimensionality and Psychometric Properties of the General Health Questionnaire-12 in a Large Scale German Population Sample. Comprehensive Psychiatry, 54(4), 406-413.

Selenko, E., Batinic, B. and Paul, K. (2011). Does latent deprivation lead to psychological distress? Investigating Jahoda's model in a four-wave study. Journal of Occupational and Organizational Psychology, 84(4), 723-740.

Solove, E., Fisher, G. G. and Kraiger, K. (2015). Coping with job loss and reemployment: A two-wave study. Journal of Business and Psychology, 30(3), 529-541.

Tait, R. J. French, D.J. and Hulse, G.K. (2003) Validity and Psychometric Properties of the General Health Questionnaire-12 in Young Australian Adolescents. Australian and New Zealand Journal of Psychiatry, $37(3), 374-381$.

Theodossiou, I. (1998). The effects of low-pay and unemployment on psychological well-being: a logistic regression approach. Journal of Health Economics, 17(1), 85-104.

Wanberg, C. R., Griffiths, R. F. and Gavin, M. B. (1997). Time structure and unemployment: A longitudinal investigation. Journal of Occupational and Organizational Psychology, 70(1), 75-95.

Wherry, F. F., Seefeldt, K. S. and Alvarez, A. S. (2019). To lend or not to lend to friends and kin: Awkwardness, obfuscation, and negative reciprocity. Social Forces, 98(2), 753-793.

Zivin, K., Paczkowski, M. and Galea, S. (2011). Economic downturns and population mental health: research findings, gaps, challenges and priorities. Psychological Medicine, 41(7), 1343-1348.

\section{Tables}

Table 1. General; Happiness Questionnaire (GHQ) Measures 
Answers

Concentration; Playing a useful role; Capable of making decisions; Enjoy day-to-day activities ; Ability to face problems and General Happiness

"More so than usual", "About the same as usual", "Less so than usual" and "Much less than usual".

Constantly under strain; Depression; Problem overcoming difficulties; Losing confidence; Believe that the respondent is worthless and Loss of sleep

"Not at all", "No more than usual", "Rather more than usual" and "Much more than usual".

Table 2. Outcome variables means and standard deviations 
PANEL A: MALES

Treated Group: Coping Strategy-Reduced Spending

Average Standard Deviation

GHQ-12 Caseness

Pre-Covid-19 Period (2015-2019)

$1.7158 \quad 3.0692$

Covid-19 Period

$2.9183 \quad 3.4444$

Treated Group: Coping Strategy-Used from Savings

GHQ-12 Caseness

Pre-Covid-19 Period (2015-2019)

$1.8071 \quad 3.1566$

Covid-19 Period

$3.4472 \quad 3.7446$

Treated Group: Coping Strategy-Borrow From Bank-Use Credit Card

GHQ-12 Caseness

Pre-Covid-19 Period (2015-2019)

$1.9424 \quad 3.1769$

Covid-19 Period

$4.6666 \quad 3.2105$

Treated Group: Coping Strategy-Borrow From Relatives and Friends

GHQ-12 Caseness

Pre-Covid-19 Period (2015-2019)

$2.5294 \quad 3.6533$

Covid-19 Period

$4.9607 \quad 4.4405$

Control Group: No coping strategy undertaken

GHQ-12 Caseness

Pre-Covid-19 Period (2015-2019)

$1.1745 \quad 2.5030$

Covid-19 Period

$1.7299 \quad 2.5777$

PANEL B: FEMALES

Treated Group: Coping Strategy-Reduced Spending Average Standard Deviation

GHQ-12 Caseness

Pre-Covid-19 Period (2015-2019)

$1.9152 \quad 3.3420$

Covid-19 Period

$3.1459 \quad 3.5210$

Treated Group: Coping Strategy-Used from Savings

GHQ-12 Caseness

Pre-Covid-19 Period (2015-2019)

$2.1780 \quad 3.3155$ 


\begin{tabular}{|c|c|c|}
\hline Covid-19 Period & 3.7336 & 3.7869 \\
\hline \multicolumn{3}{|c|}{ Treated Group: Coping Strategy-Borrow From Bank-Use Credit Card } \\
\hline \multicolumn{3}{|l|}{ GHQ-12 Caseness } \\
\hline Pre-Covid-19 Period (2015-2019) & 2.0043 & 3.5648 \\
\hline Covid-19 Period & 4.5356 & 3.9766 \\
\hline \multicolumn{3}{|c|}{ Treated Group: Coping Strategy-Borrow From Relatives and Friends } \\
\hline \multicolumn{3}{|l|}{ GHQ-12 Caseness } \\
\hline Pre-Covid-19 Period (2015-2019) & 3.0469 & 3.9889 \\
\hline Covid-19 Period & 5.7142 & 4.0647 \\
\hline \multicolumn{3}{|c|}{ Control Group: No coping strategy undertaken } \\
\hline \multicolumn{3}{|l|}{ GHQ-12 Caseness } \\
\hline Pre-Covid-19 Period (2015-2019) & 1.7616 & 3.0306 \\
\hline Covid-19 Period & 2.9220 & 2.2496 \\
\hline
\end{tabular}

Table 3. Estimates for the DiD Design (1) by Gender 


\begin{tabular}{|c|c|c|c|}
\hline \multicolumn{4}{|c|}{ Panel A1: Treated Group: Coping Strategy-Reduced Spending for Males } \\
\hline \multicolumn{2}{|l|}{ GHQ-12 Caseness } & \multicolumn{2}{|l|}{ General Happiness } \\
\hline \multirow[t]{2}{*}{ CS*Covid-19 Period } & $0.3861^{\star \star \star}$ & CS*Covid-19 Period & $0.0310^{*}$ \\
\hline & $(0.1141)$ & & $(0.0166)$ \\
\hline \multirow[t]{2}{*}{ Logarithm of Household Income } & $-0.2469 * \star \star$ & \multirow[t]{2}{*}{ Logarithm of Household Income } & $-0.0248 * \star \star$ \\
\hline & $(0.0285)$ & & $(0.0054)$ \\
\hline No. Observations & 16,884 & No. Observations & 16,884 \\
\hline R-Square & 0.0431 & R-Square & 0.0070 \\
\hline \multirow{2}{*}{$\begin{array}{l}\text { F-Statistic Test Parallel Trend } \\
\text { Assumption }\end{array}$} & 0.511 & \multirow{2}{*}{$\begin{array}{l}\text { F-Statistic Test Parallel Trend } \\
\text { Assumption }\end{array}$} & 1.923 \\
\hline & {$[0.6012]$} & & [0.1473] \\
\hline Well-being Costs & $£ 800$ & Well-being Costs & $£ 630$ \\
\hline Loss of Sleep & & Playing a Useful Role & \\
\hline \multirow[t]{2}{*}{ CS*Covid-19 Period } & $0.1089 * \star \star$ & \multirow[t]{2}{*}{ CS*Covid-19 Period } & $0.1019 * \star$ \\
\hline & $(0.0308)$ & & $(0.0449)$ \\
\hline \multirow[t]{2}{*}{ Logarithm of Household Income } & $-0.0451^{\star \star *}$ & \multirow[t]{2}{*}{ Logarithm of Household Income } & 7 \\
\hline & $(0.0118)$ & & $(0.0097)$ \\
\hline No. Observations & 16,884 & No. Observations & 16,884 \\
\hline R-Square & 0.0292 & R-Square & 0.0237 \\
\hline \multirow{2}{*}{$\begin{array}{l}\text { F-Statistic Test Parallel Trend } \\
\text { Assumption }\end{array}$} & 0.185 & \multirow{2}{*}{$\begin{array}{l}\text { F-Statistic Test Parallel Trend } \\
\text { Assumption }\end{array}$} & 1.532 \\
\hline & {$[0.8384]$} & & {$[0.2164]$} \\
\hline Well-being Costs & $£ 1,300$ & Well-being Costs & $£ 1,130$ \\
\hline Problem Overcoming difficulties & & Depression & \\
\hline \multirow[t]{2}{*}{ CS*Covid-19 Period } & $0.0765^{\star \star}$ & CS*Covid-19 Period & $0.0713^{\star \star}$ \\
\hline & $(0.0295)$ & & $(0.0327)$ \\
\hline \multirow[t]{2}{*}{ Logarithm of Household Income } & $-0.0674 * * \star$ & Logarithm of Household Income & $-0.0644 * \star \star$ \\
\hline & $(0.0073)$ & & $(0.0081)$ \\
\hline No. Observations & 16,884 & No. Observations & 16,884 \\
\hline R-Square & 0.0391 & R-Square & 0.0440 \\
\hline F-Statistic Test Parallel Trend & 0.185 & F- Statistic Test Parallel Trend & 0.185 \\
\hline
\end{tabular}




\begin{tabular}{|c|c|c|c|}
\hline Assumption & [0.8384] & Assumption & {$[0.8384]$} \\
\hline Well-being Costs & $£ 580$ & Well-being Costs & $£ 570$ \\
\hline Losing Confidence & & Believe worthless & \\
\hline \multirow[t]{2}{*}{ CS*Covid-19 Period } & $0.0799 * \star \star$ & CS*Covid-19 Period & $0.0668^{\star \star}$ \\
\hline & $(0.0307)$ & & $(0.0264)$ \\
\hline \multirow[t]{2}{*}{ Logarithm of Household Income } & $-0.0742^{\star \star \star}$ & Logarithm of Household Income & $-0.0956 * \star \star$ \\
\hline & $(0.0076)$ & & $(0.0066)$ \\
\hline No. Observations & 16,884 & No. Observations & 16,884 \\
\hline R-Square & 0.0393 & R-Square & 0.0457 \\
\hline \multirow{2}{*}{$\begin{array}{l}\text { F-Statistic Test Parallel Trend } \\
\text { Assumption }\end{array}$} & 0.185 & \multirow{2}{*}{$\begin{array}{l}\text { F-Statistic Test Parallel Trend } \\
\text { Assumption }\end{array}$} & 1.532 \\
\hline & {$[0.8384]$} & & {$[0.2164]$} \\
\hline Well-being Costs & $£ 550$ & Well-being Costs & $£ 350$ \\
\hline \multicolumn{4}{|c|}{ Panel A2: Treated Group: Coping Strategy- Used from Savings for Males } \\
\hline GHQ-12 Caseness & & General Happiness & \\
\hline \multirow[t]{2}{*}{ CS*Covid-19 Period } & $0.7951 * \star \star$ & CS*Covid-19 Period & $0.0762^{\star \star}$ \\
\hline & $(0.1644)$ & & $(0.0312)$ \\
\hline \multirow[t]{2}{*}{ Logarithm of Household Income } & 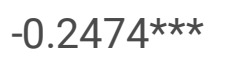 & Logarithm of Household Income & $-0.0290 * \star \star$ \\
\hline & $(0.0285)$ & & $(0.0054)$ \\
\hline No. Observations & 16,884 & No. Observations & 16,884 \\
\hline R-Square & 0.0424 & R-Square & 0.0086 \\
\hline \multirow{2}{*}{$\begin{array}{l}\text { F-Statistic Test Parallel Trend } \\
\text { Assumption }\end{array}$} & 0.135 & \multirow{2}{*}{$\begin{array}{l}\text { F-Statistic Test Parallel Trend } \\
\text { Assumption }\end{array}$} & 0.0843 \\
\hline & {$[0.8747]$} & & {$[0.9236]$} \\
\hline Well-being Costs & $£ 1,650$ & Well-being Costs & $£ 1,500$ \\
\hline Loss of Sleep & & Playing a Useful Role & \\
\hline \multirow[t]{2}{*}{ CS*Covid-19 Period } & $0.1168 * \star \star$ & CS*Covid-19 Period & $0.1132^{\star \star \star}$ \\
\hline & $(0.0277)$ & & $(0.0285)$ \\
\hline \multirow[t]{2}{*}{ Logarithm of Household Income } & $-0.0510 \star \star \star$ & Logarithm of Household Income & $-0.0494 * \star \star$ \\
\hline & $(0.0120)$ & & $(0.0098)$ \\
\hline No. Observations & 16,884 & No. Observations & 16,884 \\
\hline R-Square & 0.0227 & R-Square & 0.0224 \\
\hline
\end{tabular}


F-Statistic Test Parallel Trend Assumption

0.242

[0.7889]

$£ 1,450$

Well-being Costs
F-Statistic Test Parallel Trend Assumption

Table 3 (Cont.) Estimates for the DiD Design (1) by Gender 


\begin{tabular}{|c|c|c|c|}
\hline Capable of Making Decisions & & Constantly Under Strain & \\
\hline CS*Covid-19 Period & $0.0886^{\star \star \star}$ & CS*Covid-19 Period & $0.1462^{\star *}$ \\
\hline & $(0.0241)$ & & $(0.0846)$ \\
\hline Logarithm of Household Income & $-0.0409 * \star \star$ & Logarithm of Household Income & $-0.0464 * \star *$ \\
\hline & $(0.0041)$ & & $(0.0112)$ \\
\hline No. Observations & 16,884 & No. Observations & 16,884 \\
\hline R-Square & 0.0138 & R-Square & 0.0391 \\
\hline F-Statistic Test Parallel Trend & 1.024 & F-Statistic Test Parallel Trend & 1.024 \\
\hline & [0.3607] & & {$[0.3607]$} \\
\hline Well-being Costs & $£ 1,100$ & Well-being Costs & $£ 1,460$ \\
\hline Problem Overcoming Difficulties & & Ability to Face Problems & \\
\hline CS*Covid-19 Period & $0.1148^{\star \star \star}$ & CS*Covid-19 Period & $0.0640 * \star \star$ \\
\hline & $(0.0425)$ & & $(0.0235)$ \\
\hline Logarithm of Household Income & $-0.0699 * \star \star$ & Logarithm of Household Income & $-0.0195^{\star \star \star}$ \\
\hline & $(0.0074)$ & & $(0.0040)$ \\
\hline No. Observations & 16,884 & No. Observations & 16,884 \\
\hline R-Square & 0.0360 & R-Square & 0.0087 \\
\hline F-Statistic Test Parallel Trend & 1.024 & F-Statistic Test Parallel Trend & 1.024 \\
\hline & [0.3607] & & {$[0.3607]$} \\
\hline Well-being Costs & $£ 840$ & Well-being Costs & $£ 1,600$ \\
\hline Losing Confidence & & Believe Worthless & \\
\hline CS*Covid-19 Period & $0.0939 * \star$ & CS*Covid-19 Period & $0.0705^{\star}$ \\
\hline & $(0.0442)$ & & $(0.0381)$ \\
\hline Logarithm of Household Income & $-0.0775^{\star \star \star}$ & Logarithm of Household Income & $-0.0984^{\star \star \star}$ \\
\hline & $(0.0076)$ & & $(0.0066)$ \\
\hline No. Observations & 16,884 & No. Observations & 16,884 \\
\hline R-Square & 0.0359 & R-Square & 0.0445 \\
\hline F-Statistic Test Parallel Trend & 1.024 & F-Statistic Test Parallel Trend & 1.024 \\
\hline & {$[0.3607]$} & & {$[0.3607]$} \\
\hline
\end{tabular}




\begin{tabular}{|c|c|c|c|}
\hline Well-being Costs & $£ 620$ & Well-being Costs & $£ 360$ \\
\hline \multicolumn{4}{|c|}{ Panel A3: Treated Group: Coping Strategy-Borrow From Bank-Use Credit Card for Males } \\
\hline \multicolumn{2}{|l|}{ GHQ-12 Caseness } & \multicolumn{2}{|l|}{ General Happiness } \\
\hline \multirow[t]{2}{*}{ CS*Covid-19 Period } & $1.3055^{\star \star \star}$ & \multirow[t]{2}{*}{ CS*Covid-19 Period } & $0.1488 * \star \star$ \\
\hline & $(0.4301)$ & & $(0.0214)$ \\
\hline \multirow[t]{2}{*}{ Logarithm of Household Income } & $-0.2800 * \star \star$ & \multirow[t]{2}{*}{ Logarithm of Household Income } & $-0.0266^{\star \star *}$ \\
\hline & $(0.0284)$ & & $(0.0053)$ \\
\hline No. Observations & 16,884 & No. Observations & 16,884 \\
\hline R-Square & 0.0385 & R-Square & 0.0069 \\
\hline \multirow{2}{*}{$\begin{array}{l}\text { F-Statistic Test Parallel Trend } \\
\text { Assumption }\end{array}$} & 1.554 & \multirow{2}{*}{$\begin{array}{l}\text { F-Statistic Test Parallel Trend } \\
\text { Assumption }\end{array}$} & 0.4292 \\
\hline & {$[0.2122]$} & & {$[0.6568]$} \\
\hline Well-being Costs & $£ 2,400$ & Well-being Costs & $£ 2,800$ \\
\hline Loss of Sleep & & Playing a Useful Role & \\
\hline \multirow[t]{2}{*}{ CS*Covid-19 Period } & $0.1357 * \star$ & \multirow[t]{2}{*}{ CS*Covid-19 Period } & $0.1799 * \star$ \\
\hline & $(0.0561)$ & & $(0.0844)$ \\
\hline \multirow[t]{2}{*}{ Logarithm of Household Income } & $-0.0424 * \star \star$ & \multirow[t]{2}{*}{ Logarithm of Household Income } & $-0.0507 * \star \star$ \\
\hline & $(0.0077)$ & & $(0.0055)$ \\
\hline No. Observations & 16,884 & No. Observations & 16,884 \\
\hline R-Square & 0.0227 & R-Square & 0.0152 \\
\hline \multirow{2}{*}{$\begin{array}{l}\text { F-Statistic Test Parallel Trend } \\
\text { Assumption }\end{array}$} & 0.277 & \multirow{2}{*}{$\begin{array}{l}\text { F-Statistic Test Parallel Trend } \\
\text { Assumption }\end{array}$} & 1.539 \\
\hline & {$[0.7605]$} & & {$[0.2174]$} \\
\hline Well-being Costs & $£ 1,600$ & Well-being Costs & $£ 1,800$ \\
\hline \multicolumn{2}{|l|}{ Capable of Making Decisions } & \multicolumn{2}{|l|}{ Constantly Under Strain } \\
\hline \multirow[t]{2}{*}{ CS*Covid-19 Period } & $0.1879 * * *$ & CS*Covid-19 Period & $0.2272^{\star *}$ \\
\hline & $(0.0630)$ & & $(0.1062)$ \\
\hline \multirow[t]{2}{*}{ Logarithm of Household Income } & $-0.0439 * * *$ & Logarithm of Household Income & $-0.0501 * \star \star$ \\
\hline & $(0.0041)$ & & $(0.0111)$ \\
\hline No. Observations & 16,884 & No. Observations & 16,884 \\
\hline R-Square & 0.0117 & R-Square & 0.0386 \\
\hline F-Statistic Test Parallel Trend & 1.554 & F-Statistic Test Parallel Trend & 0.277 \\
\hline
\end{tabular}


Table 3 (Cont.) Estimates for the DiD Design (1) by Gender 


\begin{tabular}{|c|c|c|c|}
\hline Problem Overcoming Difficulties & & Enjoy Day-to-Day Activities & \\
\hline CS*Covid-19 Period & $0.2187^{\star \star}$ & CS*Covid-19 Period & $0.1732^{\star \star \star}$ \\
\hline & $(0.1112)$ & & $(0.0579)$ \\
\hline Logarithm of Household Income & $-0.0749 \star \star \star$ & Logarithm of Household Income & $-0.0458^{* * *}$ \\
\hline & $(0.0073)$ & & $(0.0058)$ \\
\hline No. Observations & 16,884 & No. Observations & 16,884 \\
\hline R-Square & 0.0339 & R-Square & 0.0422 \\
\hline F-Statistic Test Parallel Trend & 1.554 & F-Statistic Test Parallel Trend & 0.4292 \\
\hline & {$[0.2122]$} & & [0.6568] \\
\hline Well-being Costs & $£ 1,950$ & Well-being Costs & $£ 1,900$ \\
\hline Ability to Face Problems & & Depression & \\
\hline CS*Covid-19 Period & $0.2075^{\star \star \star}$ & CS*Covid-19 Period & $0.3408^{* \star *}$ \\
\hline & $(0.0614)$ & & $(0.1230)$ \\
\hline Logarithm of Household Income & $-0.0515^{\star \star \star}$ & Logarithm of Household Income & -0.0716 *** \\
\hline & $(0.0040)$ & & $(0.0081)$ \\
\hline No. Observations & 16,884 & No. Observations & 16,884 \\
\hline R-Square & 0.0079 & R-Square & 0.0400 \\
\hline F-Statistic Test Parallel Trend & 0.277 & F-Statistic Test Parallel Trend & 1.539 \\
\hline & {$[0.7605]$} & & [0.2174] \\
\hline Well-being Costs & $£ 2,050$ & Well-being Costs & $£ 2.400$ \\
\hline Losing Confidence & & Believe worthless & \\
\hline CS*Covid-19 Period & $0.2429 * \star$ & CS*Covid-19 Period & $0.3319 * \star \star$ \\
\hline & $(0.1155)$ & & $(0.0995)$ \\
\hline Logarithm of Household Income & $-0.0818^{\star \star \star}$ & Logarithm of Household Income & $-0.1020 * \star \star \star$ \\
\hline & $(0.0076)$ & & $(0.0065)$ \\
\hline No. Observations & 16,884 & No. Observations & 16,884 \\
\hline R-Square & 0.0345 & R-Square & 0.0432 \\
\hline F-Statistic Test Parallel Trend & 0.277 & F-Statistic Test Parallel Trend & 1.539 \\
\hline & {$[0.7605]$} & & {$[0.2174]$} \\
\hline
\end{tabular}


Well-being Costs $\quad £ 1,500 \quad$ Well-being Costs $£ 1,650$

\section{Panel A4: Treated Group: Coping Strategy-Borrow From Relatives and Friends for Males}

\section{GHQ-12 Caseness}

CS*Covid-19 Period

1.1137*

$(0.6260)$

Logarithm of Household Income

$-0.2792 * * *$

$(0.0284)$

No. Observations

R-Square

F-Statistic Test Parallel Trend

Assumption

Well-being Costs

Loss of Sleep

CS*Covid-19 Period

$0.2839 *$

(0.1690)

16,884

No. Observations

R-Square

F-Statistic Test Parallel Trend Assumption

[0.4497]

$£ 2,000$

Well-being Costs

Playing a Useful Role

CS*Covid-19 Period

$0.1736^{*}$

(0.0899)

Logarithm of Household Income

$-0.0421^{\star \star \star}$ Logarithm of Household Income

(0.0076)

16,884

0.0227

0.8039

[0.4497]

Assumption

$£ 510$

Well-being Costs

$0.1657 *$

F-Statistic Test Parallel Trend Assumption

No. Observations

16,884

0.0150

0.9032

[0.4066]

$£ 1,850$

\section{Believe Worthless}

Capable of Making Decisions

CS*Covid-19 Period

$0.1635^{\star \star \star}$

CS*Covid-19 Period

$(0.0417)$

$-0.0438^{* * *}$ Logarithm of Household Income

(0.0849)

Logarithm of Household Income

$(0.0041)$

16,884

No. Observations

16,884

No. Observations

R-Square

0.0115

R-Square

0.0436

F-Statistic Test Parallel Trend

0.8039

F-Statistic Test Parallel Trend

0.9032 
Table 3 (Cont.). Estimates for the DiD Design (1) by Gender 


\begin{tabular}{|c|c|c|c|}
\hline \multicolumn{4}{|c|}{ Panel B1: Treated Group: Coping Strategy-Reduced Spending for Females } \\
\hline \multicolumn{2}{|l|}{ GHQ-12 Caseness } & \multicolumn{2}{|l|}{ General Happiness } \\
\hline \multirow[t]{2}{*}{ CS*Covid-19 Period } & $0.3147^{\star \star \star}$ & CS*Covid-19 Period & 0.0158 \\
\hline & $(0.1164)$ & & $(0.0208)$ \\
\hline \multirow[t]{2}{*}{ Logarithm of Household Income } & $-0.3459 * \star \star$ & \multirow[t]{2}{*}{ Logarithm of Household Income } & $-0.0371 * * *$ \\
\hline & $(0.0276)$ & & $(0.0051)$ \\
\hline No. Observations & 23,216 & No. Observations & 23,216 \\
\hline R-Square & 0.0523 & R-Square & 0.0128 \\
\hline \multirow{2}{*}{$\begin{array}{l}\text { F-Statistic Test Parallel Trend } \\
\text { Assumption }\end{array}$} & 1.311 & \multirow{2}{*}{$\begin{array}{l}\text { F-Statistic Test Parallel Trend } \\
\text { Assumption }\end{array}$} & 0.865 \\
\hline & {$[0.2695]$} & & [0.4245] \\
\hline Well-being Costs & $£ 450$ & Well-being Costs & n.s. \\
\hline \multicolumn{2}{|l|}{ Playing a Useful Role } & \multicolumn{2}{|l|}{ Capable of Making Decisions } \\
\hline \multirow[t]{2}{*}{ CS*Covid-19 Period } & $0.1004^{\star \star}$ & \multirow[t]{2}{*}{ CS*Covid-19 Period } & $0.0480 * \star \star$ \\
\hline & $(0.0399)$ & & $(0.0158)$ \\
\hline \multirow[t]{2}{*}{ Logarithm of Household Income } & 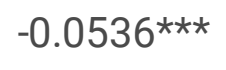 & \multirow[t]{2}{*}{ Logarithm of Household Income } & $-0.0295^{\star \star \star}$ \\
\hline & $(0.0075)$ & & $(0.0039)$ \\
\hline No. Observations & 23,216 & No. Observations & 23,216 \\
\hline R-Square & 0.0241 & R-Square & 0.0110 \\
\hline \multirow{2}{*}{$\begin{array}{l}\text { F-Statistic Test Parallel Trend } \\
\text { Assumption }\end{array}$} & 0.587 & \multirow{2}{*}{$\begin{array}{l}\text { F-Statistic Test Parallel Trend } \\
\text { Assumption }\end{array}$} & 0.587 \\
\hline & {$[0.5588]$} & & [0.5588] \\
\hline Well-being Costs & $£ 1,000$ & Well-being Costs & $£ 800$ \\
\hline \multicolumn{2}{|l|}{ Problem Overcoming Difficulties } & \multicolumn{2}{|l|}{ Enjoy Day-to-Day Activities } \\
\hline \multirow[t]{2}{*}{ CS*Covid-19 Period } & $0.0440 *$ & CS*Covid-19 Period & $0.0453^{* *}$ \\
\hline & $(0.0266)$ & & $(0.021)$ \\
\hline \multirow[t]{2}{*}{ Logarithm of Household Income } & 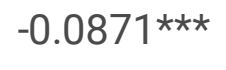 & Logarithm of Household Income & $-0.0402^{\star \star \star}$ \\
\hline & $(0.0066)$ & & $(0.0052)$ \\
\hline No. Observations & 23,216 & No. Observations & 23,216 \\
\hline R-Square & 0.0335 & R-Square & 0.0529 \\
\hline $\begin{array}{l}\text { F-Statistic Test Parallel Trend } \\
\text { Assumption }\end{array}$ & 0.587 & $\begin{array}{l}\text { F-Statistic Test Parallel Trend } \\
\text { Assumption }\end{array}$ & 0.587 \\
\hline
\end{tabular}


Well-being Costs

$£ 250$

Well-being Costs

$£ 550$

\section{Panel B2: Treated Group: Coping Strategy-Used from Savings for Females}

\section{GHQ-12 Caseness}

CS*Covid-19 Period

$0.5045^{\star \star \star}$

(0.1634)

Logarithm of Household Income

$-0.3519 * * *$

$(0.0276)$

No. Observations

R-Square

F-Statistic Test Parallel Trend

Assumption

\section{General Happiness}

CS*Covid-19 Period

$0.0505^{\star}$

(0.0305)

$-0.0373^{\star \star *}$

(0.0051)

23,216

0.0126

R-Square

F-Statistic Test Parallel Trend

Assumption

0.0843

[0.9236]

Well-being Costs

$£ 660$

\section{Loss of Sleep}

\section{Concentration}

CS*Covid-19 Period

0.0516* CS*Covid-19 Period

$0.0735^{\star}$

$(0.0281)$

(0.0404)

Logarithm of Household Income

$-0.0313^{\star \star *}$

Logarithm of Household Income

-0.0590 ***

(0.0047)

(0.0068)

No. Observations

23,216

No. Observations

23,216

R-Square

0.0242

R-Square

0.0252

F-Statistic Test Parallel Trend

Assumption

0.484

[0.6188]

F-Statistic Test Parallel Trend

Assumption

0.131

[0.8811]

Well-being Costs

$£ 810$

Well-being Costs

$£ 620$

\section{Playing a Useful Role}

CS*Covid-19 Period
$0.1763^{\star \star \star}$
(0.0619)
CS*Covid-19 Period

Logarithm of Household Income

0.1070 **

$(0.0447)$

$-0.0547 \star \star \star$ Logarithm of Household Income

$-0.0338 * \star *$

(0.0075)

$(0.0061)$

No. Observations

23,216

No. Observations

23,216

R-Square

0.0155 


\begin{tabular}{|c|c|c|c|}
\hline \multirow{2}{*}{$\begin{array}{l}\text { F-Statistic Test Parallel Trend } \\
\text { Assumption }\end{array}$} & 0.484 & \multirow{2}{*}{$\begin{array}{l}\text { F-Statistic Test Parallel Trend } \\
\text { Assumption }\end{array}$} & 0.131 \\
\hline & [0.6188] & & [0.8811] \\
\hline Well-being Costs & $£ 1,700$ & Well-being Costs & $£ 1,800$ \\
\hline
\end{tabular}

Table 3 (Cont.). Estimates for the DiD Design (1) by Gender 


\begin{tabular}{|c|c|c|c|}
\hline Problem Overcoming Difficulties & & Losing Confidence & \\
\hline CS*Covid-19 Period & $0.1393^{\star \star}$ & CS*Covid-19 Period & $0.0711^{*}$ \\
\hline & $(0.0644)$ & & $(0.0416)$ \\
\hline Logarithm of Household Income & $-0.0830 \star \star \star$ & Logarithm of Household Income & $-0.0870 * \star \star$ \\
\hline & $(0.0096)$ & & $(0.0070)$ \\
\hline No. Observations & 23,216 & No. Observations & 23,216 \\
\hline R-Square & 0.0199 & R-Square & 0.0365 \\
\hline F-Statistic Test Parallel Trend & 0.358 & F-Statistic Test Parallel Trend & 0.497 \\
\hline & {$[0.7068]$} & & [0.6143] \\
\hline Well-being Costs & $£ 780$ & Well-being Costs & $£ 400$ \\
\hline Panel B3: Treated Group: Coping & egy-Borrow F & om Bank-Use Credit Card for Femal & \\
\hline GHQ-12 Caseness & & General Happiness & \\
\hline CS*Covid-19 Period & $1.0927^{\star \star \star}$ & CS*Covid-19 Period & 0.0475 \\
\hline & $(0.3729)$ & & $(0.0696)$ \\
\hline Logarithm of Household Income & 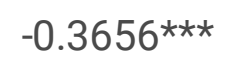 & Logarithm of Household Income & $-0.0385^{\star \star *}$ \\
\hline & $(0.0275)$ & & $(0.0051)$ \\
\hline No. Observations & 23,216 & No. Observations & 23,216 \\
\hline R-Square & 0.0498 & R-Square & 0.0124 \\
\hline F-Statistic Test Parallel Trend & 1.554 & F-Statistic Test Parallel Trend & 0.4292 \\
\hline Assumiption! & [0.2122] & & [0.6568] \\
\hline Well-being Costs & $£ 1,500$ & Well-being Costs & n.s. \\
\hline Loss of Sleep & & Playing a Useful Role & \\
\hline CS*Covid-19 Period & $0.2226^{\star \star}$ & CS*Covid-19 Period & $0.2478 * *$ \\
\hline & $(0.1073)$ & & $(0.1225)$ \\
\hline Logarithm of Household Income & $-0.0708^{\star \star \star}$ & Logarithm of Household Income & $-0.0588^{* \star *}$ \\
\hline & $(0.0098)$ & & $(0.0075)$ \\
\hline No. Observations & 23,216 & No. Observations & 23,216 \\
\hline R-Square & 0.0236 & R-Square & 0.0201 \\
\hline $\begin{array}{l}\text { F-Statistic Test Parallel Trend } \\
\text { Assumption }\end{array}$ & 0.033 & $\begin{array}{l}\text { F-Statistic Test Parallel Trend } \\
\text { Assumption }\end{array}$ & 0.681 \\
\hline
\end{tabular}




\begin{tabular}{|c|c|c|c|}
\hline \multirow{2}{*}{ Well-being Costs } & \multicolumn{2}{|l|}{ [0.9732] } & \multirow{2}{*}{$\begin{array}{l}{[0.5049]} \\
£ 2,300\end{array}$} \\
\hline & $£ 1,800$ & Well-being Costs & \\
\hline Capable of Making Decisions & & Constantly Under Strain & \\
\hline \multirow[t]{2}{*}{ CS*Covid-19 Period } & $0.1256 * *$ & CS*Covid-19 Period & $0.2095^{\star \star \star}$ \\
\hline & $(0.0529)$ & & $(0.0738)$ \\
\hline \multirow[t]{2}{*}{ Logarithm of Household Income } & $-0.0309 * * *$ & Logarithm of Household Income & $-0.0417 * * *$ \\
\hline & $(0.0039)$ & & $(0.0069)$ \\
\hline No. Observations & 16,884 & No. Observations & 16,884 \\
\hline R-Square & 0.0106 & R-Square & 0.0348 \\
\hline \multirow{2}{*}{$\begin{array}{l}\text { F-Statistic Test Parallel Trend } \\
\text { Assumption }\end{array}$} & 1.554 & \multirow{2}{*}{$\begin{array}{l}\text { F-Statistic Test Parallel Trend } \\
\text { Assumption }\end{array}$} & 0.277 \\
\hline & {$[0.2122]$} & & {$[0.7605]$} \\
\hline Well-being Costs & $£ 2,000$ & Well-being Costs & $£ 2,400$ \\
\hline Problem Overcoming Difficulties & & Losing Confidence & \\
\hline \multirow[t]{2}{*}{ CS*Covid-19 Period } & $0.2403^{\star \star *}$ & CS*Covid-19 Period & $0.2320 * \star$ \\
\hline & $(0.0890)$ & & $(0.0950)$ \\
\hline \multirow[t]{2}{*}{ Logarithm of Household Income } & $-0.0918 * \star \star$ & Logarithm of Household Income & $-0.0906 * \star \star *$ \\
\hline & $(0.0065)$ & & $(0.0070)$ \\
\hline No. Observations & 16,884 & No. Observations & 16,884 \\
\hline R-Square & 0.0308 & R-Square & 0.0350 \\
\hline \multirow{2}{*}{$\begin{array}{l}\text { F-Statistic Test Parallel Trend } \\
\text { Assumption }\end{array}$} & 1.554 & \multirow{2}{*}{$\begin{array}{l}\text { F-Statistic Test Parallel Trend } \\
\text { Assumption }\end{array}$} & 0.277 \\
\hline & [0.2122] & & [0.7605] \\
\hline Well-being Costs & $£ 1,300$ & Well-being Costs & $£ 1,250$ \\
\hline
\end{tabular}

Table 3 (Cont.) Estimates for the DiD Design (1) by Gender 


\begin{tabular}{|c|c|c|c|}
\hline \multicolumn{4}{|c|}{ Panel B4: Treated Group: Coping Strategy-Borrow From Relatives and Friends for Females } \\
\hline \multicolumn{2}{|l|}{ GHQ-12 Caseness } & \multicolumn{2}{|l|}{ General Happiness } \\
\hline \multirow[t]{2}{*}{ CS*Covid-19 Period } & $1.8619 * \star \star$ & CS*Covid-19 Period & $0.2488 * \star \star$ \\
\hline & $(0.5026)$ & & $(0.0838)$ \\
\hline \multirow[t]{2}{*}{ Logarithm of Household Income } & $-0.3529 \star \star \star$ & \multirow[t]{2}{*}{ Logarithm of Household Income } & $-0.0398^{\star \star \star}$ \\
\hline & $(0.0275)$ & & $(0.0051)$ \\
\hline No. Observations & 23,216 & No. Observations & 23,216 \\
\hline R-Square & 0.0523 & R-Square & 0.0137 \\
\hline \multirow{2}{*}{$\begin{array}{l}\text { F-Statistic Test Parallel Trend } \\
\text { Assumption }\end{array}$} & 0.8039 & \multirow{2}{*}{$\begin{array}{l}\text { F-Statistic Test Parallel Trend } \\
\text { Assumption }\end{array}$} & 0.9032 \\
\hline & [0.4497] & & {$[0.4066]$} \\
\hline Well-being Costs & $£ 2,600$ & Well-being Costs & $£ 2,800$ \\
\hline Concentration & & Loss of Sleep & \\
\hline \multirow[t]{2}{*}{ CS*Covid-19 Period } & $0.1318^{\star \star \star}$ & \multirow[t]{2}{*}{ CS*Covid-19 Period } & $0.2674 * \star \star$ \\
\hline & $(0.0365)$ & & $(0.0946)$ \\
\hline \multirow[t]{2}{*}{ Logarithm of Household Income } & $-0.0302^{\star \star \star}$ & \multirow[t]{2}{*}{ Logarithm of Household Income } & $-0.0603^{\star \star \star}$ \\
\hline & $(0.0047)$ & & $(0.0068)$ \\
\hline No. Observations & 23,216 & No. Observations & 23,216 \\
\hline R-Square & 0.0260 & R-Square & 0.0248 \\
\hline \multirow{2}{*}{$\begin{array}{l}\text { F-Statistic Test Parallel Trend } \\
\text { Assumption }\end{array}$} & 0.8039 & \multirow{2}{*}{$\begin{array}{l}\text { F-Statistic Test Parallel Trend } \\
\text { Assumption }\end{array}$} & 0.9032 \\
\hline & {$[0.4497]$} & & {$[0.4066]$} \\
\hline Well-being Costs & $£ 2,150$ & Well-being Costs & $£ 2,200$ \\
\hline Playing a Useful Role & & Capable of Making Decisions & \\
\hline \multirow[t]{2}{*}{ CS*Covid-19 Period } & $0.2435^{\star \star \star}$ & \multirow[t]{2}{*}{ CS*Covid-19 Period } & $0.2062^{\star \star *}$ \\
\hline & $(0.0926)$ & & $(0.0514)$ \\
\hline \multirow[t]{2}{*}{ Logarithm of Household Income } & $-0.0517 \star \star \star$ & \multirow[t]{2}{*}{ Logarithm of Household Income } & $-0.0395 * \star \star$ \\
\hline & $(0.0051)$ & & $(0.0039)$ \\
\hline No. Observations & 23,216 & No. Observations & 23,216 \\
\hline R-Square & 0.0201 & R-Square & 0.0123 \\
\hline $\begin{array}{l}\text { F-Statistic Test Parallel Trend } \\
\text { Assumption }\end{array}$ & 0.8039 & $\begin{array}{l}\text { F-Statistic Test Parallel Trend } \\
\text { Assumption }\end{array}$ & 0.9032 \\
\hline
\end{tabular}




\begin{tabular}{|c|c|c|c|}
\hline & [0.4497] & & {$[0.4066]$} \\
\hline Well-being Costs & $£ 2,300$ & Well-being Costs & $£ 2,600$ \\
\hline Constantly Under Strain & & Problem Overcoming Difficulties & \\
\hline CS*Covid-19 Period & $0.1802^{\star \star \star}$ & CS*Covid-19 Period & 0 5026t*t \\
\hline & $(0.0565)$ & & \\
\hline & & & (0.1199) \\
\hline Logarithm of Household Income & $-0.0378^{\star \star \star}$ & Logarithm of Household Income & $-0.0887 \star \star \star$ \\
\hline & $(0.0069)$ & & $(0.0066)$ \\
\hline No. Observations & 23,216 & No. Observations & 23,216 \\
\hline R-Square & 0.0359 & R-Square & 0.0332 \\
\hline F-Statistic Test Parallel Trend & 0.8039 & F-Statistic Test Parallel Trend & 0.9032 \\
\hline ASsuाmption & [0.4497] & Assumiption & {$[0.4066]$} \\
\hline Well-being Costs & $£ 2,350$ & Well-being Costs & $£ 3,000$ \\
\hline Enjoy Day-to-Day Activities & & Ability to Face Problems & \\
\hline CS*Covid-19 Period & $0.1736^{\star \star \star}$ & CS*Covid-19 Period & 010 \\
\hline & $(0.0658)$ & & \\
\hline & & & \\
\hline Logarithm of Household Income & $-0.0388^{\star \star \star}$ & Logarithm of Household Income & $-0.0347 \star \star \star *$ \\
\hline & $(0.0052)$ & & $(0.0039)$ \\
\hline No. Observations & 23,216 & No. Observations & 23,216 \\
\hline R-Square & 0.0536 & R-Square & 0.0111 \\
\hline F-Statistic Test Parallel Trend & 0.8039 & F-Statistic Test Parallel Trend & 0.9032 \\
\hline & {$[0.4497]$} & & {$[0.4066]$} \\
\hline Well-being Costs & $£ 2,200$ & Well-being Costs & $£ 2,700$ \\
\hline
\end{tabular}

Standard errors in the brackets and clustered at the individual level. P-values within the square brackets. $\star \star \star, * \star$ and $*$ indicate significance at $1 \%, 5 \%$ and $10 \%$ level. Regressions are weighted by the sampling survey weight. n.s. denotes no significant.

Table 4. Estimates for the DiD Design (1) by Race 


\begin{tabular}{|c|c|c|c|}
\hline \multicolumn{4}{|c|}{ Panel A1: Treated Group: Coping Strategy-Reduced Spending for White British } \\
\hline \multicolumn{2}{|l|}{ GHQ-12 Caseness } & \multicolumn{2}{|l|}{ General Happiness } \\
\hline \multirow[t]{2}{*}{ CS*Covid-19 Period } & $0.2846 \star \star$ & \multirow[t]{2}{*}{ CS*Covid-19 Period } & 0.0289 \\
\hline & $(0.1378)$ & & $(0.0306)$ \\
\hline \multirow[t]{2}{*}{ Logarithm of Household Income } & $-0.3575^{\star \star \star}$ & \multirow[t]{2}{*}{ Logarithm of Household Income } & $-0.0423^{* * *}$ \\
\hline & $(0.0414)$ & & $(0.0078)$ \\
\hline No. Observations & 30,896 & No. Observations & 30,896 \\
\hline R-Square & 0.0643 & R-Square & 0.0137 \\
\hline \multirow{2}{*}{$\begin{array}{l}\text { F-Statistic Test Parallel Trend } \\
\text { Assumption }\end{array}$} & 2.274 & \multirow{2}{*}{$\begin{array}{l}\text { F-Statistic Test Parallel Trend } \\
\text { Assumption }\end{array}$} & 2.182 \\
\hline & {$[0.1031]$} & & [0.1132] \\
\hline Well-being Costs & $£ 400$ & Well-being Costs & n.s. \\
\hline \multicolumn{4}{|c|}{ Panel A2: Treated Group: Coping Strategy- Used from Savings for White British } \\
\hline \multicolumn{2}{|l|}{ GHQ-12 Caseness } & \multicolumn{2}{|l|}{ General Happiness } \\
\hline \multirow[t]{2}{*}{ CS*Covid-19 Period } & $0.9680 * \star \star$ & \multirow[t]{2}{*}{ CS*Covid-19 Period } & \\
\hline & $(0.2328)$ & & $(0.0298)$ \\
\hline \multirow[t]{2}{*}{ Logarithm of Household Income } & $-0.3680 \star \star \star *$ & \multirow[t]{2}{*}{ Logarithm of Household Income } & $-0.0422 * \star \star$ \\
\hline & $(0.0415)$ & & $(0.0078)$ \\
\hline No. Observations & 30,896 & No. Observations & 30,896 \\
\hline R-Square & 0.0632 & R-Square & 0.0171 \\
\hline \multirow{2}{*}{$\begin{array}{l}\text { F-Statistic Test Parallel Trend } \\
\text { Assumption }\end{array}$} & 0.208 & \multirow{2}{*}{$\begin{array}{l}\text { F-Statistic Test Parallel Trend } \\
\text { Assumption }\end{array}$} & 0.371 \\
\hline & [0.8195] & & [0.6873] \\
\hline Well-being Costs & $£ 1,300$ & Well-being Costs & $£ 710$ \\
\hline \multicolumn{4}{|c|}{ Panel A3: Treated Group: Coping Strategy-Borrow From Bank-Use Credit Card for White British } \\
\hline \multicolumn{2}{|l|}{ GHQ-12 Caseness } & \multicolumn{2}{|l|}{ General Happiness } \\
\hline \multirow[t]{2}{*}{ CS*Covid-19 Period } & $1.4380^{\star \star \star *}$ & \multirow[t]{2}{*}{ CS*Covid-19 Period } & 012 \\
\hline & $(0.5091)$ & & $(0.0608)$ \\
\hline \multirow[t]{2}{*}{ Logarithm of Household Income } & $-0.3897 * \star \star$ & \multirow[t]{2}{*}{ Logarithm of Household Income } & $-0.0440 * * \star$ \\
\hline & $(0.0412)$ & & $(0.0077)$ \\
\hline
\end{tabular}




\begin{tabular}{|c|c|c|c|}
\hline No. Observations & 30,896 & No. Observations & 30,896 \\
\hline R-Square & 0.0595 & R-Square & 0.0163 \\
\hline \multirow{2}{*}{$\begin{array}{l}\text { F-Statistic Test Parallel Trend } \\
\text { Assumption }\end{array}$} & 1.307 & \multirow{2}{*}{$\begin{array}{l}\text { F-Statistic Test Parallel Trend } \\
\text { Assumption }\end{array}$} & 1.424 \\
\hline & [0.2733] & & [0.2406] \\
\hline Well-being Costs & $£ 1,800$ & Well-being Costs & $£ 1,450$ \\
\hline \multicolumn{4}{|c|}{ Panel A4: Treated Group: Coping Strategy-Borrow From Relatives and Friends for White British } \\
\hline \multicolumn{2}{|l|}{ GHQ-12 Caseness } & \multicolumn{2}{|l|}{ General Happiness } \\
\hline \multirow[t]{3}{*}{ CS*Covid-19 Period } & 1.5216 & \multirow[t]{3}{*}{ CS*Covid-19 Period } & \\
\hline & $(0.9633)$ & & \\
\hline & & & $(0.1000)$ \\
\hline \multirow[t]{2}{*}{ Logarithm of Household Income } & $-0.3722 * \star \star$ & \multirow[t]{2}{*}{ Logarithm of Household Income } & $-0.0416 * \star \star$ \\
\hline & $(0.0409)$ & & $(0.0077)$ \\
\hline No. Observations & 30,896 & No. Observations & 30,896 \\
\hline R-Square & 0.0639 & R-Square & 0.0184 \\
\hline \multirow{2}{*}{$\begin{array}{l}\text { F-Statistic Test Parallel Trend } \\
\text { Assumption }\end{array}$} & 1.115 & \multirow{2}{*}{$\begin{array}{l}\text { F-Statistic Test Parallel Trend } \\
\text { Assumption }\end{array}$} & 0.704 \\
\hline & [0.3286] & & [0.4953] \\
\hline Well-being Costs & n.s. & Well-being Costs & $£ 2,850$ \\
\hline \multicolumn{4}{|c|}{ Panel B1: Treated Group: Coping Strategy-Reduced Spending for Other White } \\
\hline \multicolumn{2}{|l|}{ GHQ-12 Caseness } & \multicolumn{2}{|l|}{ General Happiness } \\
\hline \multirow[t]{2}{*}{ CS*Covid-19 Period } & $0.9756^{\star}$ & \multirow[t]{2}{*}{ CS*Covid-19 Period } & 0.1391 \\
\hline & $(0.5214)$ & & $(0.1145)$ \\
\hline \multirow[t]{2}{*}{ Logarithm of Household Income } & $-0.3693^{\star \star}$ & \multirow[t]{2}{*}{ Logarithm of Household Income } & $-0.0731 * \star$ \\
\hline & $(0.1655)$ & & $(0.0307)$ \\
\hline No. Observations & 2,216 & No. Observations & 2,216 \\
\hline R-Square & 0.1600 & R-Square & 0.0787 \\
\hline \multirow{2}{*}{$\begin{array}{l}\text { F-Statistic Test Parallel Trend } \\
\text { Assumption }\end{array}$} & 0.245 & \multirow{2}{*}{$\begin{array}{l}\text { F-Statistic Test Parallel Trend } \\
\text { Assumption }\end{array}$} & 0.344 \\
\hline & {$[0.7875]$} & & [0.7142] \\
\hline Well-being Costs & $£ 1,450$ & Well-being Costs & n.s. \\
\hline
\end{tabular}


Table 4 (Cont.) Estimates for the DiD Design (1) by Race 


\begin{tabular}{|c|c|c|c|}
\hline \multicolumn{4}{|c|}{ Panel B2: Treated Group: Coping Strategy- Used from Savings for Other White } \\
\hline \multicolumn{2}{|l|}{ GHQ-12 Caseness } & \multicolumn{2}{|l|}{ General Happiness } \\
\hline \multirow[t]{2}{*}{ CS*Covid-19 Period } & 1.1817 & \multirow[t]{2}{*}{ CS*Covid-19 Period } & $0.2948 *$ \\
\hline & $(0.8589)$ & & $(0.1708)$ \\
\hline \multirow[t]{2}{*}{ Logarithm of Household Income } & $-0.3983^{\star \star}$ & \multirow[t]{2}{*}{ Logarithm of Household Income } & $-0.0776 * \star$ \\
\hline & $(0.1691)$ & & $(0.0323)$ \\
\hline No. Observations & 2,216 & No. Observations & 2,216 \\
\hline R-Square & 0.1584 & R-Square & 0.0803 \\
\hline \multirow{2}{*}{$\begin{array}{l}\text { F-Statistic Test Parallel Trend } \\
\text { Assumption }\end{array}$} & 1.133 & \multirow{2}{*}{$\begin{array}{l}\text { F-Statistic Test Parallel Trend } \\
\text { Assumption }\end{array}$} & 0.165 \\
\hline & [0.3218] & & [0.8511] \\
\hline Well-being Costs & n.s. & Well-being Costs & $£ 2,050$ \\
\hline \multicolumn{4}{|c|}{ Panel B3: Treated Group: Coping Strategy-Borrow From Bank-Use Credit Card for Other White } \\
\hline \multicolumn{2}{|l|}{ GHQ-12 Caseness } & \multicolumn{2}{|l|}{ General Happiness } \\
\hline \multirow[t]{2}{*}{ CS*Covid-19 Period } & $2.2801 * \star \star$ & \multirow[t]{2}{*}{ CS*Covid-19 Period } & 0.1359 \\
\hline & $(0.7805)$ & & $(0.2294)$ \\
\hline \multirow[t]{2}{*}{ Logarithm of Household Income } & $-0.4385^{\star \star \star}$ & \multirow[t]{2}{*}{ Logarithm of Household Income } & $-0.0868 * \star \star x$ \\
\hline & $(0.1653)$ & & $(0.0322)$ \\
\hline No. Observations & 2,216 & No. Observations & 2,216 \\
\hline R-Square & 0.1625 & R-Square & 0.0746 \\
\hline \multirow{2}{*}{$\begin{array}{l}\text { F-Statistic Test Parallel Trend } \\
\text { Assumption }\end{array}$} & 1.267 & \multirow{2}{*}{$\begin{array}{l}\text { F-Statistic Test Parallel Trend } \\
\text { Assumption }\end{array}$} & 0.730 \\
\hline & {$[0.2826]$} & & {$[0.4844]$} \\
\hline Well-being Costs & $£ 2,800$ & Well-being Costs & n.s. \\
\hline \multicolumn{4}{|c|}{ Panel B4: Treated Group: Coping Strategy-Borrow From Relatives and Friends for Other White } \\
\hline \multicolumn{2}{|l|}{ GHQ-12 Caseness } & \multicolumn{2}{|l|}{ General Happiness } \\
\hline \multirow[t]{2}{*}{ CS*Covid-19 Period } & $1.6302^{\star \star \star}$ & CS*Covid-19 Period & 0.3082 \\
\hline & $(1.1915)$ & & $(0.3656)$ \\
\hline \multirow[t]{2}{*}{ Logarithm of Household Income } & $-0.3290 \star \star$ & Logarithm of Household Income & $-0.0744^{\star \star}$ \\
\hline & $(0.1651)$ & & $(0.0326)$ \\
\hline No. Observations & 2,216 & No. Observations & 2,216 \\
\hline
\end{tabular}




\begin{tabular}{|c|c|c|c|}
\hline R-Square & 0.1910 & R-Square & 0.0903 \\
\hline \multirow{2}{*}{$\begin{array}{l}\text { F-Statistic Test Parallel Trend } \\
\text { Assumption }\end{array}$} & 1.734 & \multirow{2}{*}{$\begin{array}{l}\text { F-Statistic Test Parallel Trend } \\
\text { Assumption }\end{array}$} & 2.786 \\
\hline & {$[0.1787]$} & & {$[0.0627]$} \\
\hline Well-being Costs & $£ 2,700$ & Well-being Costs & n.s. \\
\hline \multicolumn{4}{|c|}{ Panel C1: Treated Group: Coping Strategy-Reduced Spending for Mixed White } \\
\hline \multicolumn{2}{|l|}{ GHQ-12 Caseness } & \multicolumn{2}{|l|}{ General Happiness } \\
\hline \multirow[t]{2}{*}{ CS*Covid-19 Period } & $1.5813^{\star}$ & \multirow[t]{2}{*}{ CS*Covid-19 Period } & $0.3050 *$ \\
\hline & $(0.9205)$ & & $(0.1717)$ \\
\hline \multirow[t]{2}{*}{ Logarithm of Household Income } & $-0.0388 * \star \star$ & \multirow[t]{2}{*}{ Logarithm of Household Income } & $-0.1087^{\star \star *}$ \\
\hline & $(0.0052)$ & & $(0.0370)$ \\
\hline No. Observations & 964 & No. Observations & 964 \\
\hline R-Square & 0.0536 & R-Square & 0.2448 \\
\hline \multirow{2}{*}{$\begin{array}{l}\text { F-Statistic Test Parallel Trend } \\
\text { Assumption }\end{array}$} & 1.276 & \multirow{2}{*}{$\begin{array}{l}\text { F-Statistic Test Parallel Trend } \\
\text { Assumption }\end{array}$} & 1.402 \\
\hline & {$[0.2810]$} & & {$[0.2480]$} \\
\hline Well-being Costs & $£ 1,300$ & Well-being Costs & $£ 1,580$ \\
\hline \multicolumn{4}{|c|}{ Panel C2: Treated Group: Coping Strategy-Used from Savings for Mixed White } \\
\hline \multicolumn{2}{|l|}{ GHQ-12 Caseness } & \multicolumn{2}{|l|}{ General Happiness } \\
\hline \multirow[t]{2}{*}{ CS*Covid-19 Period } & 0.0920 & \multirow[t]{2}{*}{ CS*Covid-19 Period } & 0.0516 \\
\hline & $(0.1100)$ & & $(0.0872)$ \\
\hline \multirow[t]{2}{*}{ Logarithm of Household Income } & $-0.6206 * \star$ & \multirow[t]{2}{*}{ Logarithm of Household Income } & $-0.0347^{\star \star *}$ \\
\hline & $(0.2628)$ & & $(0.0039)$ \\
\hline No. Observations & 964 & No. Observations & 964 \\
\hline R-Square & 0.3414 & R-Square & 0.2525 \\
\hline \multirow{2}{*}{$\begin{array}{l}\text { F-Statistic Test Parallel Trend } \\
\text { Assumption }\end{array}$} & 1.143 & \multirow{2}{*}{$\begin{array}{l}\text { F-Statistic Test Parallel Trend } \\
\text { Assumption }\end{array}$} & 0.195 \\
\hline & [0.3213] & & {$[0.8311]$} \\
\hline Well-being Costs & n.s. & Well-being Costs & n.s. \\
\hline
\end{tabular}

Table 4 (Cont.) Estimates for the DiD Design (1) by Race 


\begin{tabular}{|c|c|c|c|}
\hline \multicolumn{4}{|c|}{ Panel C3: Treated Group: Coping Strategy-Borrow From Bank-Use Credit Card for Mixed White } \\
\hline \multicolumn{2}{|l|}{ GHQ-12 Caseness } & \multicolumn{2}{|l|}{ General Happiness } \\
\hline \multirow[t]{2}{*}{ CS*Covid-19 Period } & 0.1009 & \multirow[t]{2}{*}{ CS*Covid-19 Period } & $0.3539 * \star$ \\
\hline & $(0.1750)$ & & $(0.1658)$ \\
\hline \multirow[t]{2}{*}{ Logarithm of Household Income } & $-0.5897 *$ & \multirow[t]{2}{*}{ Logarithm of Household Income } & $-0.0689 * \star$ \\
\hline & $(0.3287)$ & & $(0.0325)$ \\
\hline No. Observations & 964 & No. Observations & 964 \\
\hline R-Square & 0.3331 & R-Square & 0.2409 \\
\hline \multirow{2}{*}{$\begin{array}{l}\text { F-Statistic Test Parallel Trend } \\
\text { Assumption }\end{array}$} & 0.320 & \multirow{2}{*}{$\begin{array}{l}\text { F-Statistic Test Parallel Trend } \\
\text { Assumption }\end{array}$} & 0.287 \\
\hline & [0.7233] & & [0.7551] \\
\hline Well-being Costs & n.s. & Well-being Costs & $£ 2,900$ \\
\hline \multicolumn{4}{|c|}{ Panel C4: Treated Group: Coping Strategy-Borrow From Relatives and Friends for Mixed White } \\
\hline \multicolumn{2}{|l|}{ GHQ-12 Caseness } & \multicolumn{2}{|l|}{ General Happiness } \\
\hline \multirow[t]{2}{*}{ CS*Covid-19 Period } & 1.4077 & \multirow[t]{2}{*}{ CS*Covid-19 Period } & $0.5562^{\star \star}$ \\
\hline & $(1.7940)$ & & $(0.2758)$ \\
\hline \multirow[t]{2}{*}{ Logarithm of Household Income } & $-0.7586^{\star \star}$ & \multirow[t]{2}{*}{ Logarithm of Household Income } & $-0.0873^{\star *}$ \\
\hline & $(0.3403)$ & & $(0.0423)$ \\
\hline No. Observations & 964 & No. Observations & 964 \\
\hline R-Square & 0.3315 & R-Square & 0.2851 \\
\hline \multirow{2}{*}{$\begin{array}{l}\text { F-Statistic Test Parallel Trend } \\
\text { Assumption }\end{array}$} & 1.825 & \multirow{2}{*}{$\begin{array}{l}\text { F-Statistic Test Parallel Trend } \\
\text { Assumption }\end{array}$} & 1.808 \\
\hline & {$[0.1628]$} & & [0.1659] \\
\hline Well-being Costs & n.s. & Well-being Costs & $£ 3,600$ \\
\hline \multicolumn{4}{|c|}{$\begin{array}{l}\text { Panel D1: Treated Group: Coping Strategy-Reduced Spending for Indians, Pakistanis and } \\
\text { Bangladeshis }\end{array}$} \\
\hline \multicolumn{2}{|l|}{ GHQ-12 Caseness } & \multicolumn{2}{|l|}{ General Happiness } \\
\hline \multirow[t]{2}{*}{ CS*Covid-19 Period } & $2.3940 * \star \star$ & CS*Covid-19 Period & $0.3778 * \star \star$ \\
\hline & $(0.6651)$ & & $(0.1213)$ \\
\hline \multirow[t]{2}{*}{ Logarithm of Household Income } & $-0.3790 * \star$ & Logarithm of Household Income & $-0.0600 * *$ \\
\hline & $(0.1829)$ & & $(0.0245)$ \\
\hline No. Observations & 3,484 & No. Observations & 3,484 \\
\hline
\end{tabular}




\begin{tabular}{|c|c|c|c|}
\hline R-Square & 0.1759 & R-Square & 0.1300 \\
\hline \multirow{2}{*}{$\begin{array}{l}\text { F-Statistic Test Parallel Trend } \\
\text { Assumption }\end{array}$} & 1.968 & \multirow{2}{*}{$\begin{array}{l}\text { F-Statistic Test Parallel Trend } \\
\text { Assumption }\end{array}$} & 0.554 \\
\hline & [0.1410] & & [0.5796] \\
\hline Well-being Costs & $£ 3,200$ & Well-being Costs & $£ 2,550$ \\
\hline
\end{tabular}

\section{Panel D2: Treated Group: Coping Strategy- Used from Savings for Indians, Pakistanis and Bangladeshis}

\section{GHQ-12 Caseness}

CS*Covid-19 Period
1.0973 CS*Covid-19 Period

$(0.7101)$

\section{General Happiness}

$0.2747 * *$

$-0.4145^{\star \star} \quad$ Logarithm of Household Income

$-0.0862^{\star *}$

(0.1899)

\begin{tabular}{|c|c|c|c|}
\hline No. Observations & 3,484 & No. Observations & 3,484 \\
\hline R-Square & 0.1565 & R-Square & 0.1232 \\
\hline \multirow{2}{*}{$\begin{array}{l}\text { F-Statistic Test Parallel Trend } \\
\text { Assumption }\end{array}$} & 1.021 & \multirow{2}{*}{$\begin{array}{l}\text { F-Statistic Test Parallel Trend } \\
\text { Assumption }\end{array}$} & 1.924 \\
\hline & [0.3608] & & [0.1469] \\
\hline Well-being Costs & n.s. & Well-being Costs & $£ 2,850$ \\
\hline
\end{tabular}

\section{Panel D3: Treated Group: Coping Strategy-Borrow From Bank-Use Credit Card for Indians, Pakistanis and Bangladeshis}

\section{GHQ-12 Caseness}

CS*Covid-19 Period

1.2489*** CS*Covid-19 Period

(0.4169)

\section{General Happiness}

$-0.4505^{\star \star} \quad$ Logarithm of Household Income $\quad 0.0722^{\star}$

(0.1866)

$3,484 \quad$ No. Observations 3,484

$0.1561 \quad$ R-Square 0.1225

$1.723 \quad$ F-Statistic Test Parallel Trend $\quad 2.136$

[0.1794] Assumption

[0.1197]

Well-being Costs
Well-being Costs n.s. 
Table 4 (Cont.) Estimates for the DiD Design (1) by Race 


\begin{tabular}{|c|c|c|c|}
\hline GHQ-12 Caseness & & General Happiness & \\
\hline \multirow[t]{2}{*}{ CS*Covid-19 Period } & 2.3732 & \multirow[t]{2}{*}{ CS*Covid-19 Period } & $0.6149 * * *$ \\
\hline & $(1.5961)$ & & $(0.2057)$ \\
\hline \multirow[t]{2}{*}{ Logarithm of Household Income } & $-0.4333^{\star \star}$ & \multirow[t]{2}{*}{ Logarithm of Household Income } & $-0.0958 * \star$ \\
\hline & $(0.1874)$ & & $(0.0451)$ \\
\hline No. Observations & 3,484 & No. Observations & 3,484 \\
\hline R-Square & 0.1561 & R-Square & 0.1252 \\
\hline \multirow{2}{*}{$\begin{array}{l}\text { F-Statistic Test Parallel Trend } \\
\text { Assumption }\end{array}$} & 0.020 & \multirow{2}{*}{$\begin{array}{l}\text { F-Statistic Test Parallel Trend } \\
\text { Assumption }\end{array}$} & 0.219 \\
\hline & {$[0.9753]$} & & {$[0.8075]$} \\
\hline Well-being Costs & n.s. & Well-being Costs & $£ 3,000$ \\
\hline
\end{tabular}

\section{Panel E1: Treated Group: Coping Strategy-Reduced Spending for Asians}

\section{GHQ-12 Caseness}

CS*Covid-19 Period

0.8403

(1.1693)

\section{General Happiness}

CS*Covid-19 Period

0.1108

$(0.2433)$

Logarithm of Household Income

$-0.5489 \star \star$

Logarithm of Household Income

$-0.0395^{\star *}$

(0.2269)

No. Observations

596

0.4071

1.426

[0.2423]

F-Statistic Test
Assumption

n.s.
(0.0187)

No. Observations

596

0.1564

0.859

[0.4302]

n.s.

\section{Panel E2: Treated Group: Coping Strategy- Used from Savings for Asians}

\section{GHQ-12 Caseness}

CS*Covid-19 Period

0.8847

(2.1369)

Logarithm of Household Income

-0.4704 **

(0.2313)

\section{General Happiness}

CS*Covid-19 Period

0.4223

(0.4658)

Logarithm of Household Income

$-0.0385^{\star *}$

(0.0172)

No. Observations

596

No. Observations

596 


\begin{tabular}{|c|c|c|c|}
\hline R-Square & 0.4046 & R-Square & 0.1659 \\
\hline \multirow{2}{*}{$\begin{array}{l}\text { F-Statistic Test Parallel Trend } \\
\text { Assumption }\end{array}$} & 0.813 & \multirow{2}{*}{$\begin{array}{l}\text { F-Statistic Test Parallel Trend } \\
\text { Assumption }\end{array}$} & 0.149 \\
\hline & [0.4438] & & {$[0.8656]$} \\
\hline Well-being Costs & n.s. & Well-being Costs & n.s. \\
\hline \multicolumn{4}{|c|}{ Panel E3: Treated Group: Coping Strategy- Borrow From Relatives-Friends for Asians } \\
\hline GHQ-12 Caseness & & General Happiness & \\
\hline \multirow[t]{2}{*}{ CS*Covid-19 Period } & $3.4740 * \star$ & \multirow[t]{2}{*}{ CS*Covid-19 Period } & $0.4832^{\star}$ \\
\hline & $(1.4145)$ & & $(0.2580)$ \\
\hline \multirow[t]{2}{*}{ Logarithm of Household Income } & $-0.7301 * \star$ & \multirow[t]{2}{*}{ Logarithm of Household Income } & $-0.0703 * \star$ \\
\hline & $(0.3485)$ & & $(0.0291)$ \\
\hline No. Observations & 1,944 & No. Observations & 1,944 \\
\hline R-Square & 0.2373 & R-Square & 0.2192 \\
\hline \multirow{2}{*}{$\begin{array}{l}\text { F-Statistic Test Parallel Trend } \\
\text { Assumption }\end{array}$} & 0.276 & \multirow{2}{*}{$\begin{array}{l}\text { F-Statistic Test Parallel Trend } \\
\text { Assumption }\end{array}$} & 0.295 \\
\hline & [0.7543] & & [0.7223] \\
\hline Well-being Costs & $£ 2,900$ & Well-being Costs & $£ 3,500$ \\
\hline
\end{tabular}

Table 4 (Cont.) Estimates for the DiD Design (1) by Race 


\begin{tabular}{|c|c|c|c|}
\hline \multicolumn{4}{|c|}{ Panel F1: Treated Group: Reduced Spending for Africans, Black Caribbean and Arabs } \\
\hline \multicolumn{2}{|l|}{ GHQ-12 Caseness } & \multicolumn{2}{|l|}{ General Happiness } \\
\hline \multirow[t]{2}{*}{ CS*Covid-19 Period } & $0.5196 * \star$ & \multirow[t]{2}{*}{ CS*Covid-19 Period } & $0.3008 *$ \\
\hline & $(0.2417)$ & & $(0.1752)$ \\
\hline \multirow[t]{2}{*}{ Logarithm of Household Income } & $-0.5655^{\star \star \star}$ & \multirow[t]{2}{*}{ Logarithm of Household Income } & $-0.1279 * \star$ \\
\hline & $(0.1196)$ & & $(0.0597)$ \\
\hline No. Observations & 1,944 & No. Observations & 1,944 \\
\hline R-Square & 0.3225 & R-Square & 0.2192 \\
\hline \multirow{2}{*}{$\begin{array}{l}\text { F-Statistic Test Parallel Trend } \\
\text { Assumption }\end{array}$} & 1.830 & \multirow{2}{*}{$\begin{array}{l}\text { F-Statistic Test Parallel Trend } \\
\text { Assumption }\end{array}$} & 0.662 \\
\hline & {$[0.1616]$} & & [0.5159] \\
\hline Well-being Costs & $£ 750$ & Well-being Costs & $£ 1,300$ \\
\hline \multicolumn{4}{|c|}{$\begin{array}{l}\text { Panel F2: Treated Group: Coping Strategy- Used from Savings for Africans, Black Caribbean and } \\
\text { Arabs }\end{array}$} \\
\hline \multicolumn{2}{|l|}{ GHQ-12 Caseness } & \multicolumn{2}{|l|}{ General Happiness } \\
\hline \multirow[t]{2}{*}{ CS*Covid-19 Period } & $1.4325^{\star \star}$ & \multirow[t]{2}{*}{ CS*Covid-19 Period } & 0.5828 \\
\hline & $(0.6821)$ & & $(0.4782)$ \\
\hline \multirow[t]{2}{*}{ Logarithm of Household Income } & $-0.7716^{\star \star \star}$ & \multirow[t]{2}{*}{ Logarithm of Household Income } & $-0.0742^{\star \star *}$ \\
\hline & $(0.2655)$ & & $(0.0226)$ \\
\hline No. Observations & 1,944 & No. Observations & 1,944 \\
\hline R-Square & 0.2199 & R-Square & 0.2496 \\
\hline \multirow{2}{*}{$\begin{array}{l}\text { F-Statistic Test Parallel Trend } \\
\text { Assumption }\end{array}$} & 0.326 & \multirow{2}{*}{$\begin{array}{l}\text { F-Statistic Test Parallel Trend } \\
\text { Assumption }\end{array}$} & 0.419 \\
\hline & {$[0.7265]$} & & [0.6629] \\
\hline Well-being Costs & $£ 1,000$ & Well-being Costs & n.s. \\
\hline \multicolumn{4}{|c|}{ Panel F3: Treated Group: Coping Strategy-Borrow From Bank for Africans, Black Caribbean and Arabs } \\
\hline \multicolumn{2}{|l|}{ GHQ-12 Caseness } & \multicolumn{2}{|l|}{ General Happiness } \\
\hline \multirow[t]{2}{*}{ CS*Covid-19 Period } & $3.4951 * \star \star$ & CS*Covid-19 Period & $0.5743^{\star \star \star}$ \\
\hline & $(0.8738)$ & & $(0.1911)$ \\
\hline \multirow[t]{2}{*}{ Logarithm of Household Income } & 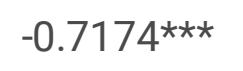 & Logarithm of Household Income & $-0.0926 * \star$ \\
\hline & $(0.2302)$ & & $(0.0451)$ \\
\hline No. Observations & 1,944 & No. Observations & 1,944 \\
\hline
\end{tabular}




\begin{tabular}{|c|c|c|c|}
\hline R-Square & 0.3225 & R-Square & 0.2808 \\
\hline \multirow{2}{*}{$\begin{array}{l}\text { F-Statistic Test Parallel Trend } \\
\text { Assumption }\end{array}$} & 0.8039 & \multirow{2}{*}{$\begin{array}{l}\text { F-Statistic Test Parallel Trend } \\
\text { Assumption }\end{array}$} & 0.9032 \\
\hline & [0.4497] & & {$[0.4066]$} \\
\hline Well-being Costs & $£ 2,700$ & Well-being Costs & $£ 3,250$ \\
\hline \multicolumn{4}{|c|}{$\begin{array}{l}\text { Panel F4: Treated Group: Coping Strategy-Borrow From Relatives-Friends for Africans, Black } \\
\text { Caribbean and Arabs }\end{array}$} \\
\hline GHQ-12 Caseness & & General Happiness & \\
\hline \multirow[t]{2}{*}{ CS*Covid-19 Period } & $2.1100 * \star \star$ & CS*Covid-19 Period & $0.8856 * * \star$ \\
\hline & $(0.2704)$ & & $(0.2380)$ \\
\hline \multirow[t]{2}{*}{ Logarithm of Household Income } & $-0.7950 \star \star \star$ & \multirow[t]{2}{*}{ Logarithm of Household Income } & $-0.1311^{\star \star}$ \\
\hline & $(0.2599)$ & & $(0.0558)$ \\
\hline No. Observations & 1,944 & No. Observations & 1,944 \\
\hline R-Square & 0.2237 & R-Square & 0.2121 \\
\hline \multirow{2}{*}{$\begin{array}{l}\text { F-Statistic Test Parallel Trend } \\
\text { Assumption }\end{array}$} & 1.238 & \multirow{2}{*}{$\begin{array}{l}\text { F-Statistic Test Parallel Trend } \\
\text { Assumption }\end{array}$} & 1.944 \\
\hline & {$[0.2937]$} & & {$[0.1440]$} \\
\hline Well-being Costs & $£ 1,800$ & Well-being Costs & $£ 3,400$ \\
\hline
\end{tabular}

Standard errors in the brackets and clustered at the individual level. P-values within the square brackets. $\star \star \star, * \star$ and $*$ indicate significance at $1 \%, 5 \%$ and $10 \%$ level. Regressions are weighted by the sampling survey weight. n.s. denotes no significant.

Table 5. Robustness Checks 


\begin{tabular}{|c|c|c|c|}
\hline \multicolumn{4}{|c|}{ Panel A: Treated Group: Coping Strategy-Reduced Spending for Males Ordered Logit } \\
\hline \multicolumn{2}{|l|}{ GHQ-12 Caseness } & \multicolumn{2}{|l|}{ General Happiness } \\
\hline \multirow[t]{2}{*}{ CS*Covid-19 Period } & $0.0503^{\star *}$ & \multirow[t]{2}{*}{ CS*Covid-19 Period } & $0.1928 *$ \\
\hline & $(0.0238)$ & & $(0.1061)$ \\
\hline \multirow[t]{2}{*}{ Logarithm of Household Income } & 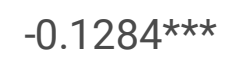 & \multirow[t]{2}{*}{ Logarithm of Household Income } & $-0.2003^{* * *}$ \\
\hline & $(0.0219)$ & & $(0.0268)$ \\
\hline No. Observations & 16,884 & No. Observations & 16,884 \\
\hline \multirow[t]{2}{*}{ LR Chi-Square } & $1,189.76$ & \multirow[t]{2}{*}{ LR Chi-Square } & 328.54 \\
\hline & {$[0.000]$} & & {$[0.000]$} \\
\hline \multirow{2}{*}{$\begin{array}{l}\text { F-Statistic Test Parallel Trend } \\
\text { Assumption }\end{array}$} & 3.108 & \multirow{2}{*}{$\begin{array}{l}\text { F-Statistic Test Parallel Trend } \\
\text { Assumption }\end{array}$} & 4.375 \\
\hline & [0.2118] & & {$[0.1152]$} \\
\hline Well-being Costs & $£ 760$ & Well-being Costs & $£ 700$ \\
\hline \multicolumn{4}{|c|}{ Panel B: Treated Group: Coping Strategy-Reduced Spending for Males FE-OLS } \\
\hline \multicolumn{2}{|l|}{ GHQ-12 Caseness } & \multicolumn{2}{|l|}{ General Happiness } \\
\hline \multirow[t]{2}{*}{ CS*Covid-19 Period } & $0.4572^{\star \star \star}$ & \multirow[t]{2}{*}{ CS*Covid-19 Period } & $0.0333 *$ \\
\hline & $(0.0933)$ & & $(0.0182)$ \\
\hline \multirow[t]{2}{*}{ Logarithm of Household Income } & $-0.2882^{\star \star}$ & \multirow[t]{2}{*}{ Logarithm of Household Income } & $-0.0260 * * *$ \\
\hline & $(0.1353)$ & & $(0.0086)$ \\
\hline No. Observations & 16,884 & No. Observations & 16,884 \\
\hline R-Square & 0.0257 & R-Square & 0.0015 \\
\hline \multirow{2}{*}{$\begin{array}{l}\text { F-Statistic Test Parallel Trend } \\
\text { Assumption }\end{array}$} & 0.233 & \multirow{2}{*}{$\begin{array}{l}\text { F-Statistic Test Parallel Trend } \\
\text { Assumption }\end{array}$} & 1.560 \\
\hline & {$[0.7949]$} & & {$[0.2099]$} \\
\hline Well-being Costs & $£ 870$ & Well-being Costs & $£ 680$ \\
\hline \multicolumn{4}{|c|}{ Panel C: Treated Group: Coping Strategy-Reduced Spending for Males Random Effects Ordered Logit } \\
\hline \multicolumn{2}{|l|}{ GHQ-12 Caseness } & \multicolumn{2}{|l|}{ General Happiness } \\
\hline \multirow[t]{2}{*}{ CS*Covid-19 Period } & $0.1375^{\star \star}$ & \multirow[t]{2}{*}{ CS*Covid-19 Period } & $0.1663^{*}$ \\
\hline & $(0.0596)$ & & $(0.0917)$ \\
\hline \multirow[t]{2}{*}{ Logarithm of Household Income } & $-0.1087 \star \star \star$ & \multirow[t]{2}{*}{ Logarithm of Household Income } & $-0.0864^{* * *}$ \\
\hline & $(0.0322)$ & & $(0.0329)$ \\
\hline
\end{tabular}




\begin{tabular}{|c|c|c|c|}
\hline No. Observations & 16,884 & No. Observations & 16,884 \\
\hline \multirow[t]{2}{*}{ Wald Chi-Square } & $1,040.89$ & \multirow[t]{2}{*}{ Wald Chi-Square } & 313.25 \\
\hline & {$[0.000]$} & & {$[0.000]$} \\
\hline \multirow{2}{*}{$\begin{array}{l}\text { F-Statistic Test Parallel Trend } \\
\text { Assumption }\end{array}$} & 0.144 & \multirow{2}{*}{$\begin{array}{l}\text { F-Statistic Test Parallel Trend } \\
\text { Assumption }\end{array}$} & 0.296 \\
\hline & [0.8725] & & [0.7503] \\
\hline Well-being Costs & $£ 750$ & Well-being Costs & $£ 650$ \\
\hline \multicolumn{4}{|c|}{ Panel D: Treated Group: Coping Strategy-Reduced Spending for Males PSM FE_OLS } \\
\hline Loss of Sleep & & Playing a Useful Role & \\
\hline \multirow[t]{2}{*}{ CS*Covid-19 Period } & 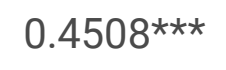 & \multirow[t]{2}{*}{ CS*Covid-19 Period } & $0.0342 * \star$ \\
\hline & $(0.1490)$ & & $(0.0161)$ \\
\hline \multirow[t]{2}{*}{ Logarithm of Household Income } & $-0.2816 * \star \star$ & \multirow[t]{2}{*}{ Logarithm of Household Income } & 000 \\
\hline & $(0.0431)$ & & $(0.0081)$ \\
\hline No. Observations & 8,488 & No. Observations & 8,488 \\
\hline R-Square & 0.0513 & R-Square & 0.0174 \\
\hline \multirow{2}{*}{$\begin{array}{l}\text { F-Statistic Test Parallel Trend } \\
\text { Assumption }\end{array}$} & 0.577 & \multirow{2}{*}{$\begin{array}{l}\text { F-Statistic Test Parallel Trend } \\
\text { Assumption }\end{array}$} & 0.106 \\
\hline & [0.5630] & & [0.9086] \\
\hline Well-being Costs & $£ 840$ & Well-being Costs & $£ 660$ \\
\hline
\end{tabular}

Standard errors in the brackets and clustered at the individual level. P-values within the square brackets. $\star \star \star, ~ * \star$ and * indicate significance at $1 \%, 5 \%$ and $10 \%$ level. Regressions are weighted by the sampling survey weight.

\section{Figures}




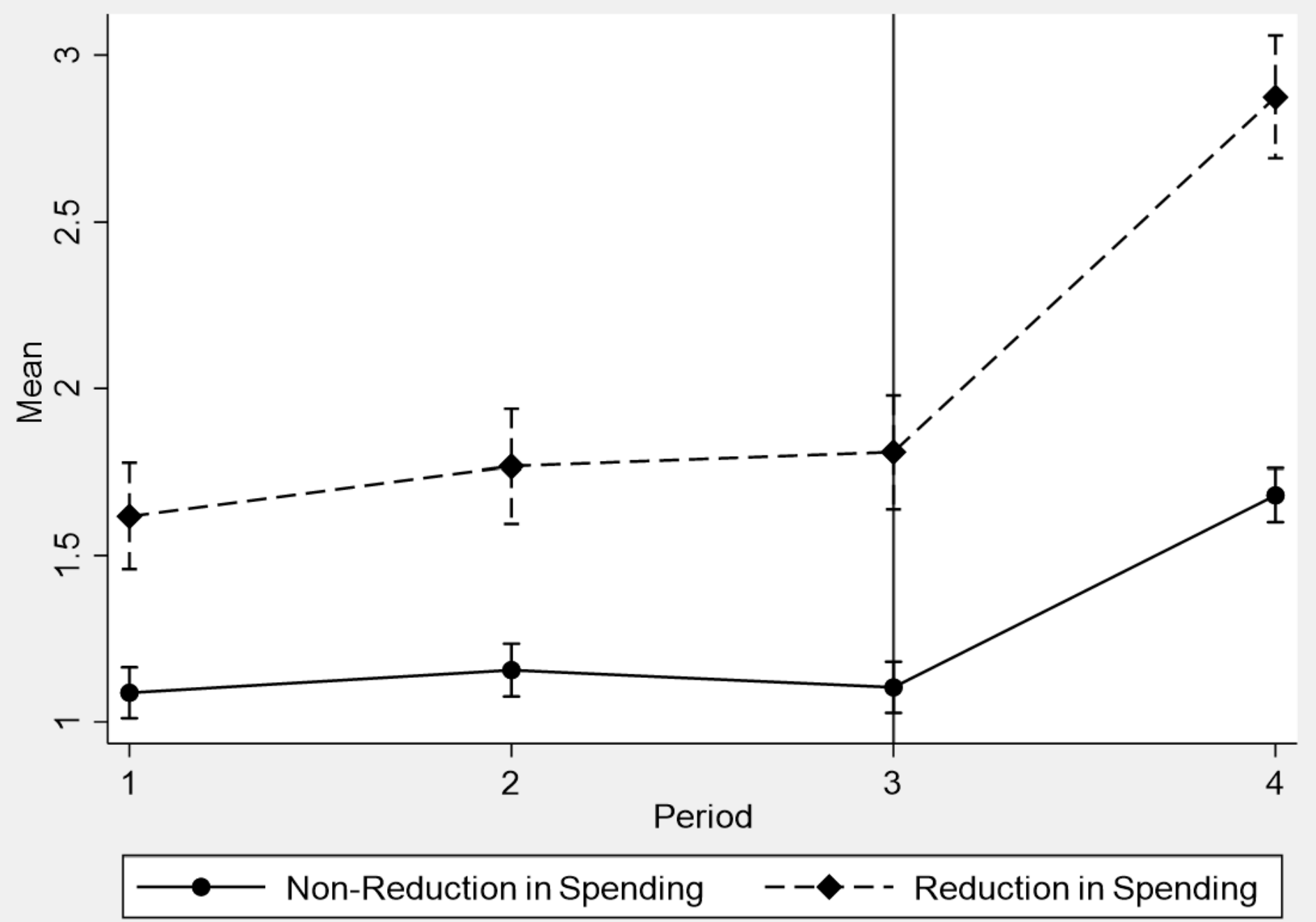

Figure 1

GHQ-12 and Reduce Spending for Males 


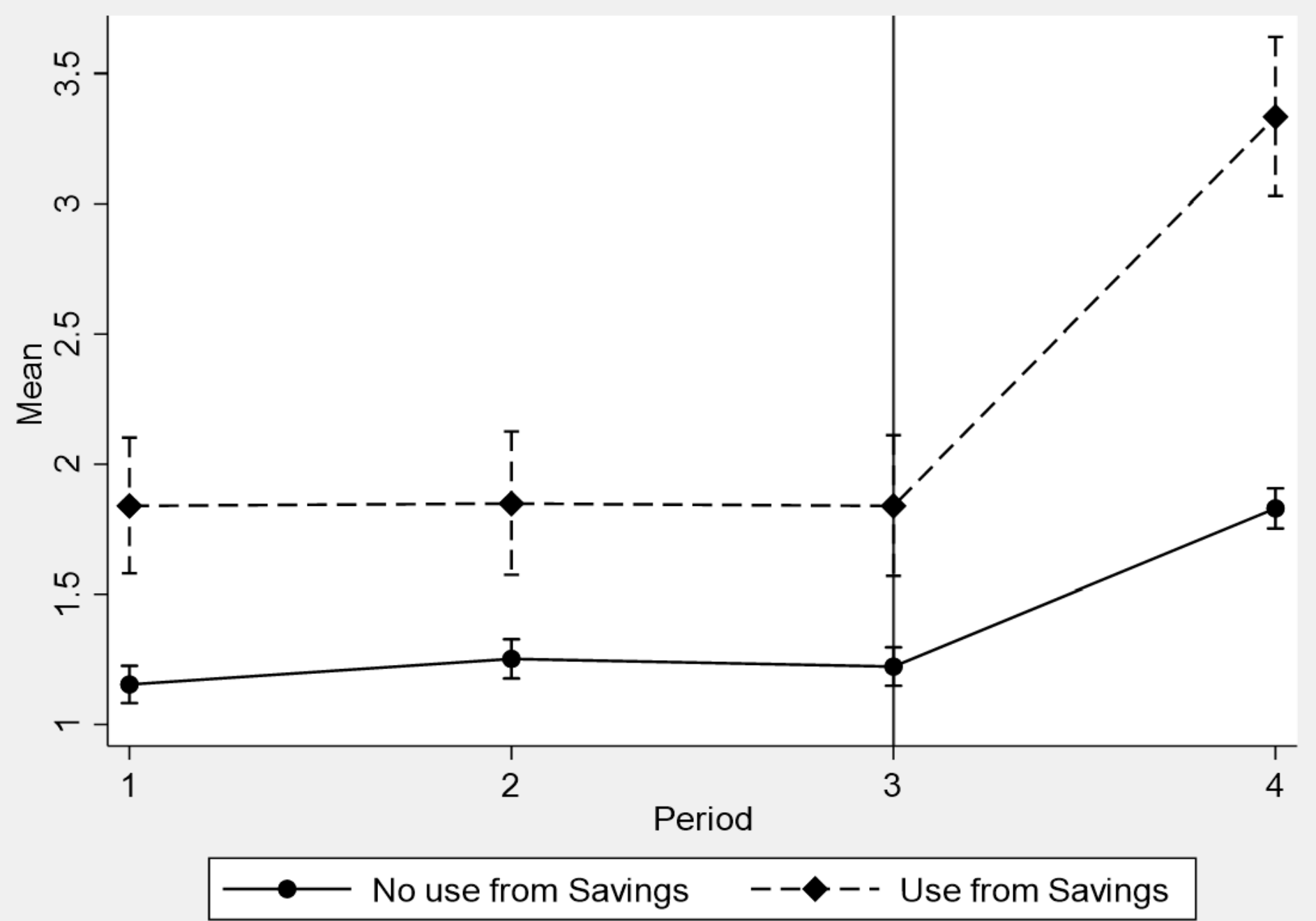

Figure 2

GHQ-12 and Use from Savings for Males 


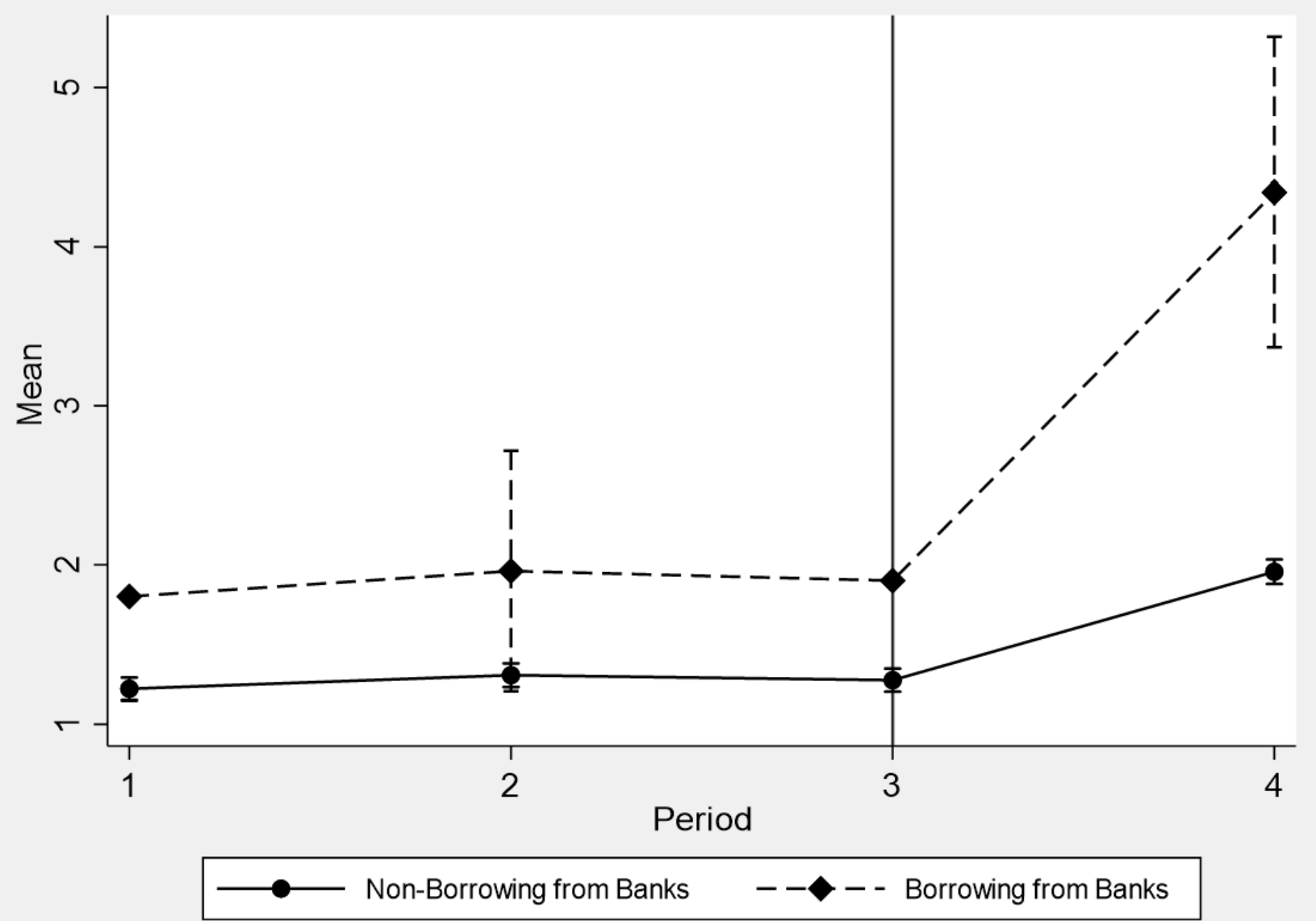

Figure 3

GHQ-12 and Borrowing from Banks or Use Crdit Cards for Males 


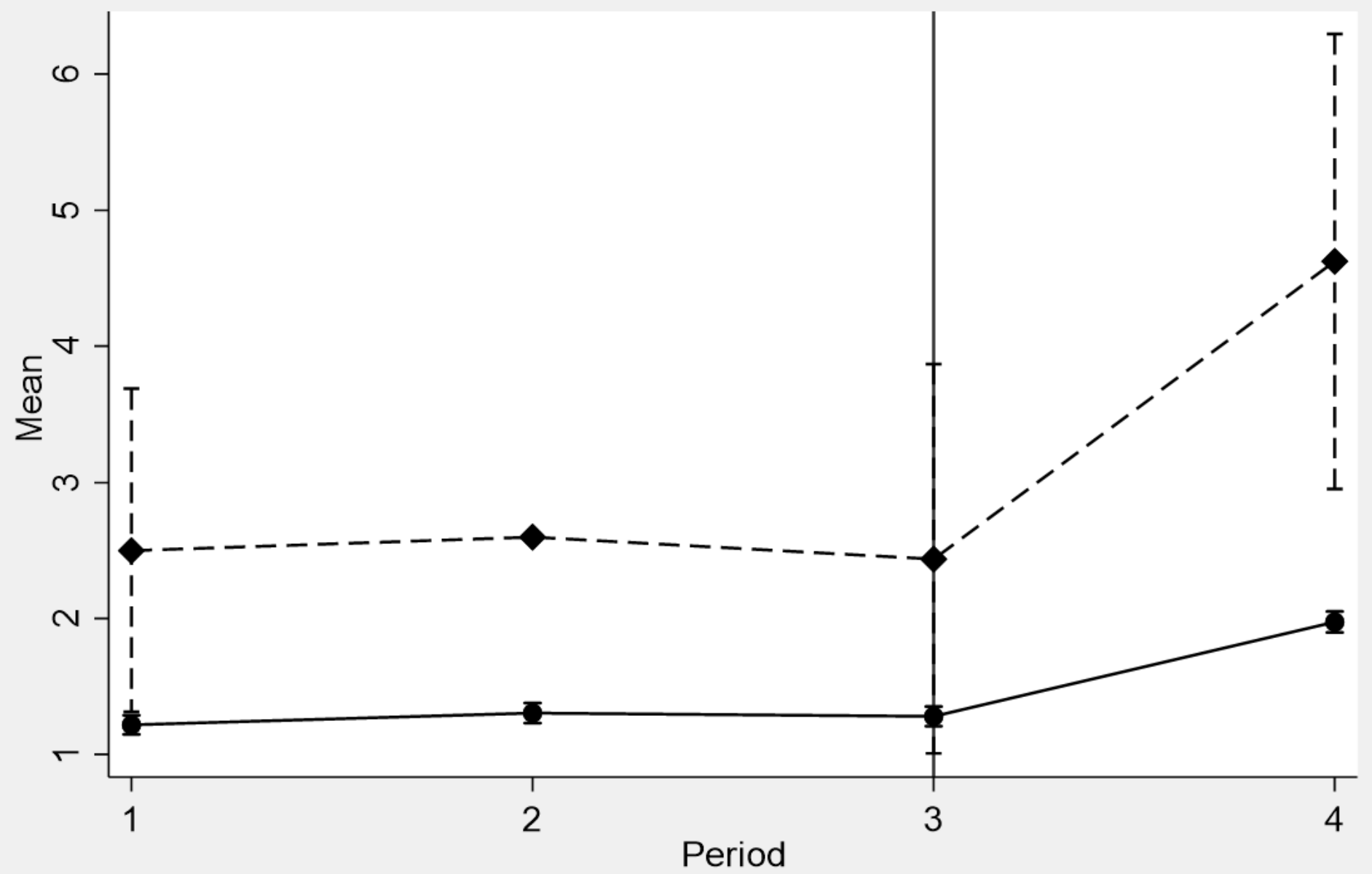

Non-Borrowing from Family-Friends $-\downarrow-$ Borrowing from Family-Friends

Figure 4

GHQ-12 and Borrowing from Relatives and Friends for Males 


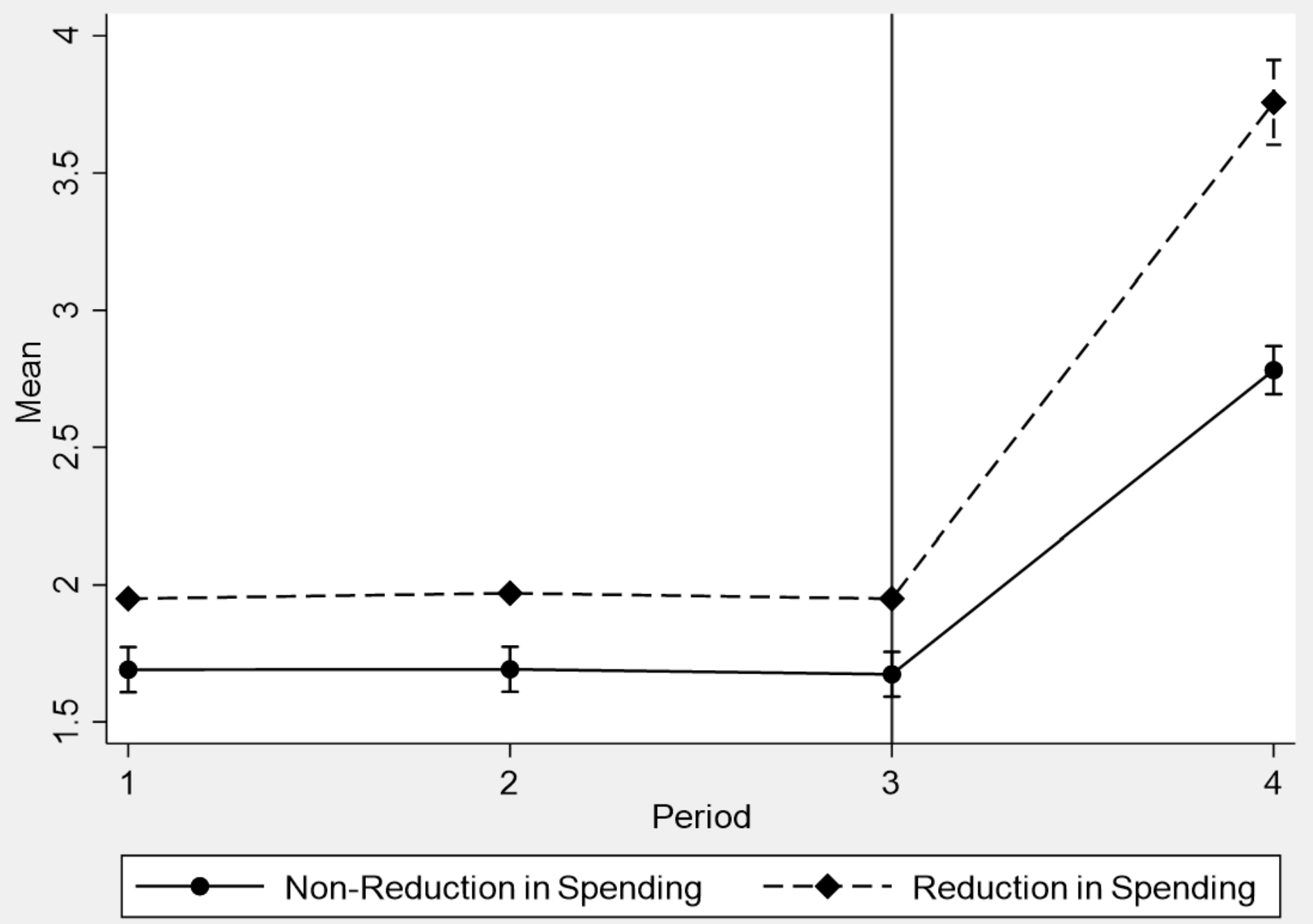

Figure 5

GHQ-12 and Reduce Spending for Females 


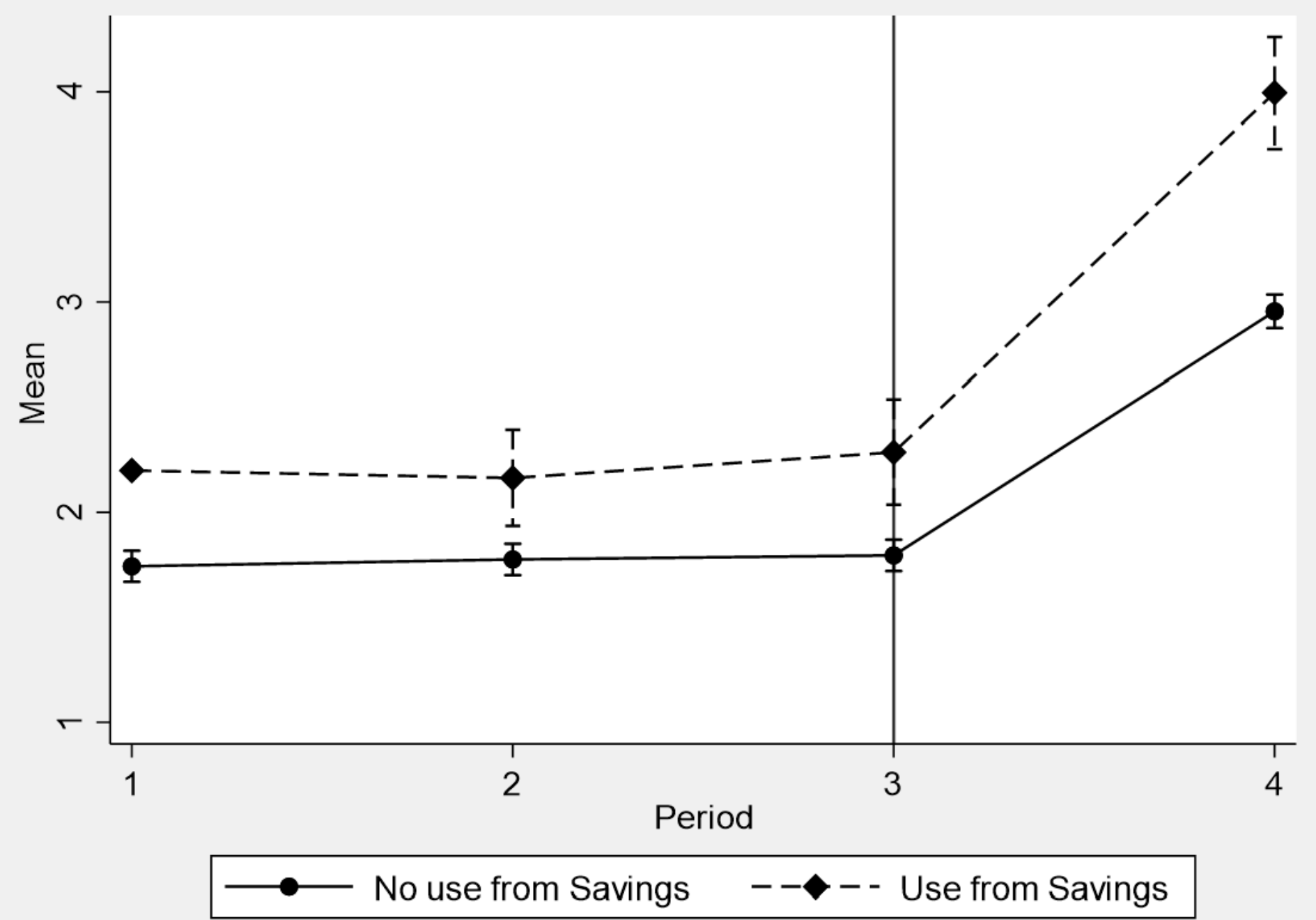

Figure 6

GHQ-12 and Use from Savings for Females 


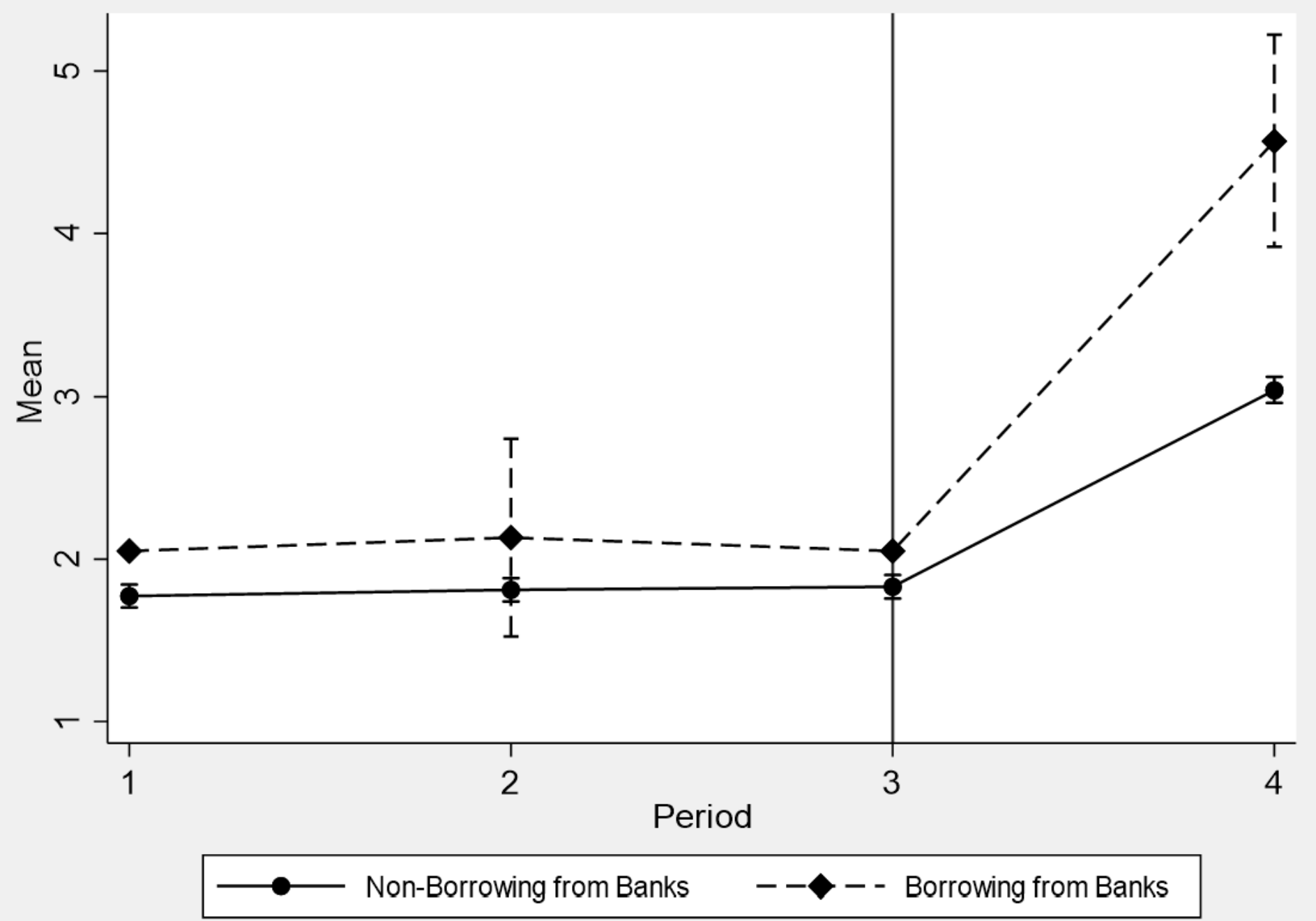

Figure 7

GHQ-12 and Borrowing from Banks or Use Credit Cards for Females 


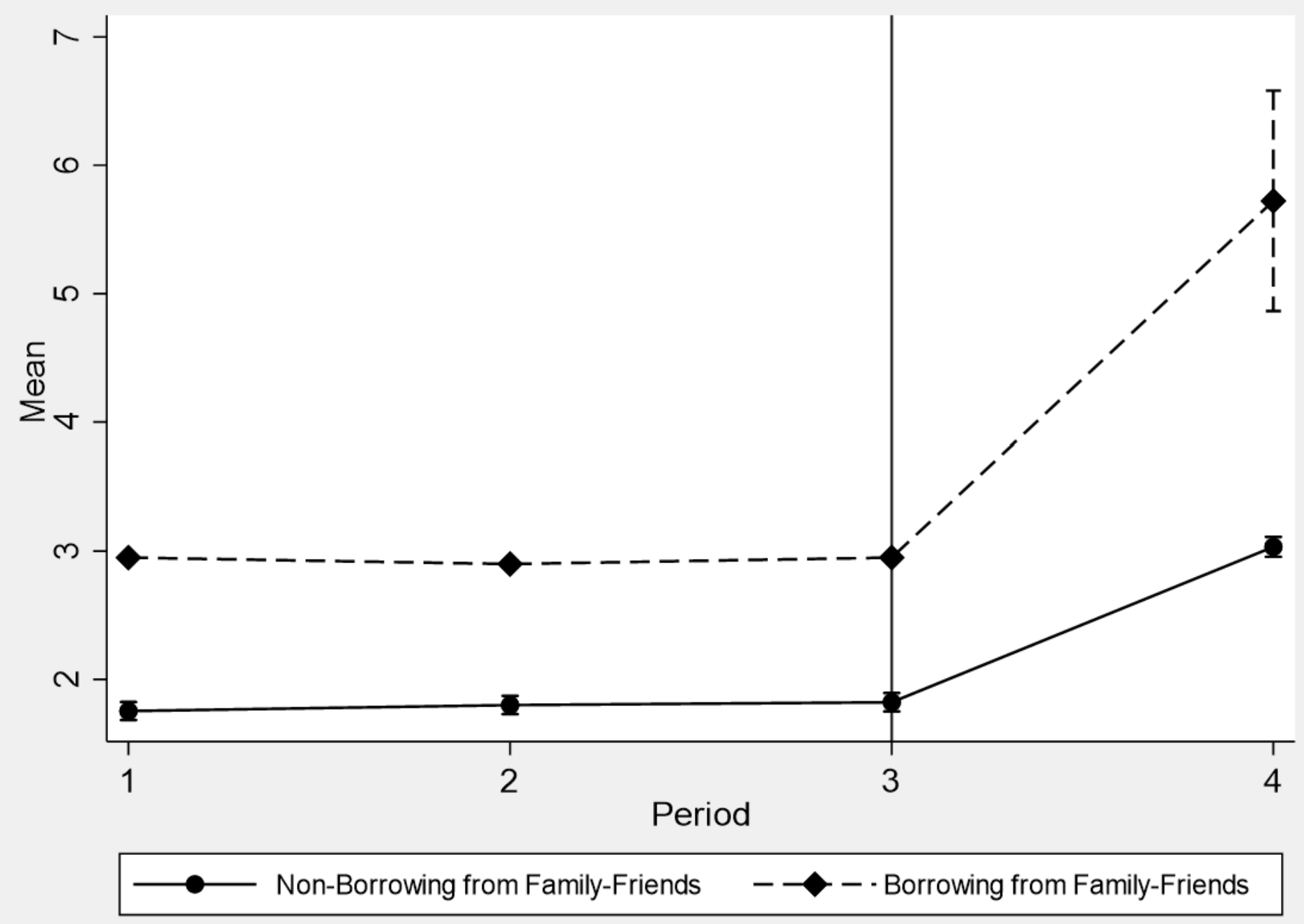

Figure 8

GHQ-12 and Borrowing from Relatives and Friends for Females 


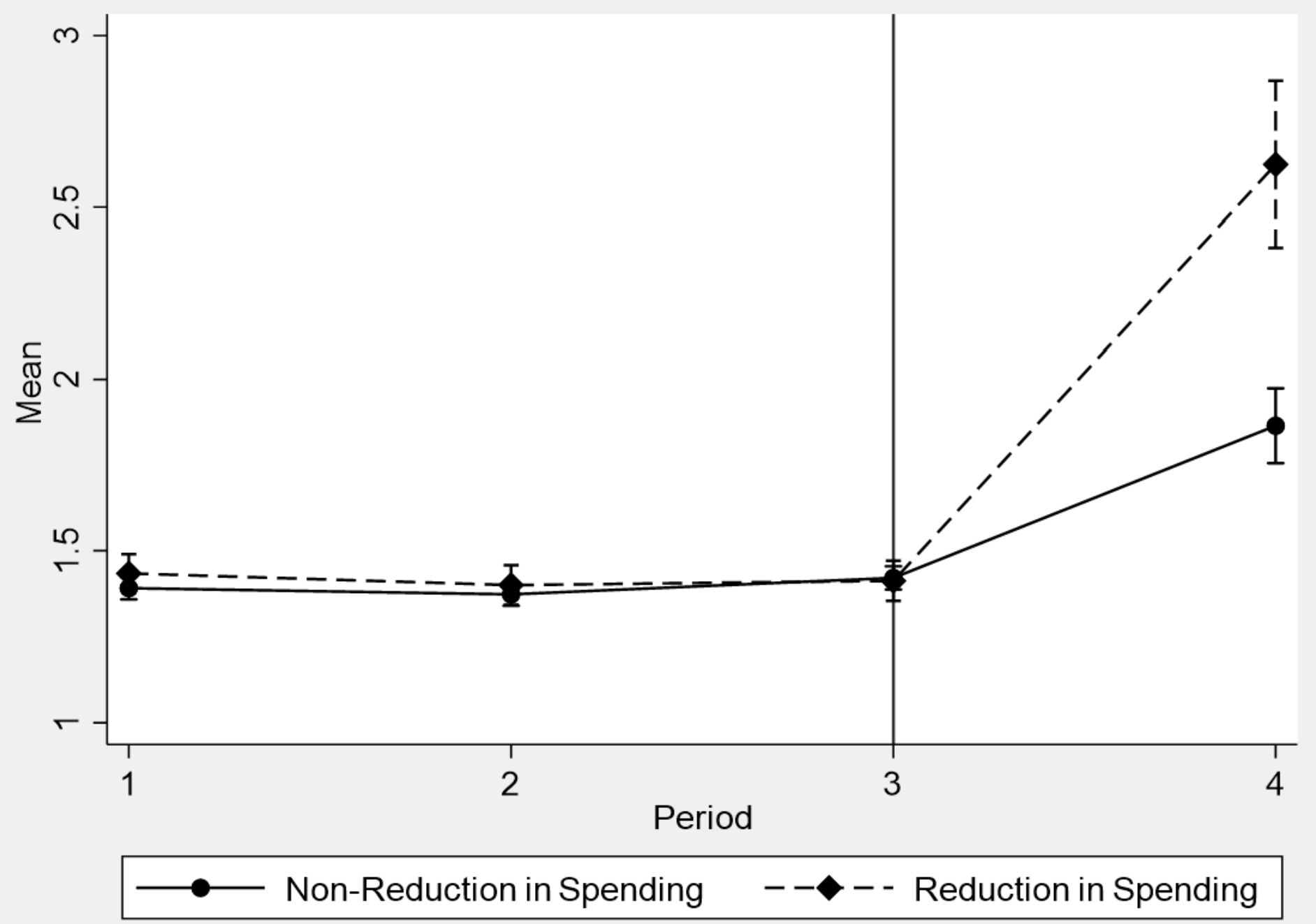

Figure 9

GHQ-12 and Reduce Spending for Males using the Macthed Sample 


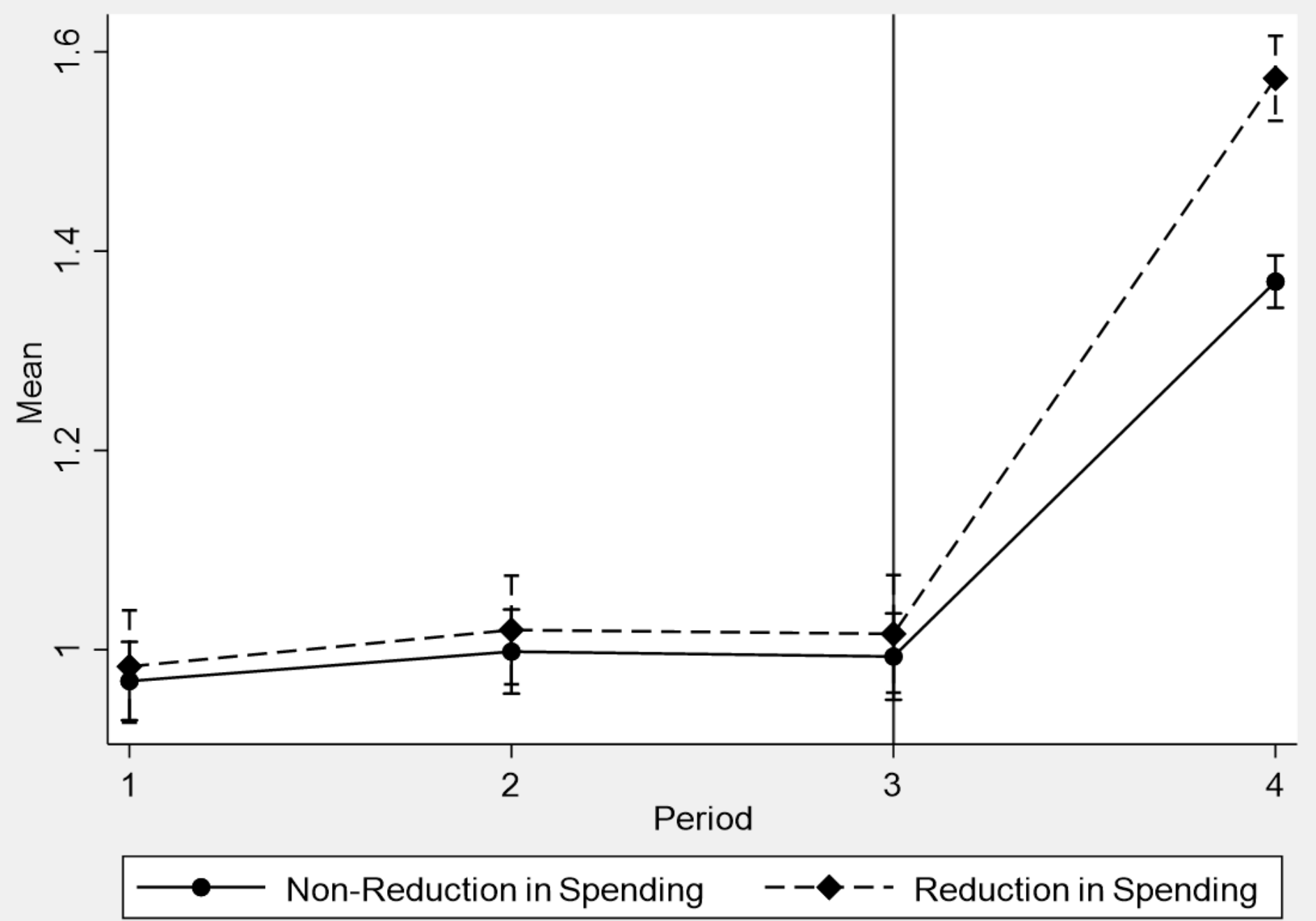

Figure 10

General Happiness and Reduce Spending for Males using the Macthed Sample 